\title{
1. Convergence in the EU: What role for industrial relations?
}

\section{Daniel Vaughan-Whitehead and Rosalia Vazquez-Alvarez}

\section{INTRODUCTION}

Convergence in wealth and living standards represents one major objective of the European Community construction, as recently evidenced by the objectives of the European Pillar of Social Rights (EC 2017a, 2017b). The aim of this volume is to provide insights into economic and social convergence trends in the European Union (EU) and to better identify the possible contribution of industrial relations to such trends.

While the literature on convergence to date has focused mainly on economic convergence - notably by means of comparing gross domestic product (GDP) per capita between countries over time - the contributors to this volume look at the convergence of European Union countries (EU28) on a greater number of socio-economic dimensions, as evidenced in each of the independent chapters that comprise the volume.

In addition to the contribution of each individual chapter, the aim of this first chapter is to better understand the importance of convergence as one major objective of EU construction and the place it is currently taking in the European Commission (EC) policy agenda (section 2).

We then present some of the main inputs from the national chapters, which reconstitute their country's national story in terms of convergence, and provide some evidence of the impact of industrial relations on convergence (section 3). The experts in their different chapters offer statistical analyses and, when data are sparse, illustrate their national convergence story with a number of in-depth case studies, including a number of cross-country studies. This introduction does not aim at summarising convergence among the country studies but, rather, to provide some analysis of how industrial relations may have helped to explain country trends in terms of convergence in labour and social indicators.

We then present some trends in social and economic convergence among the EU28 through a series of social and labour indicators, taking as a basis the European Pillar of Social Rights (section 4). The selection of indicators was decided by the experts' group who in their national chapters in the volume further illustrate national differences in socio-economic dynamics across Europe. This EU28 comparative analysis is conducted with the aim of identifying trends and convergence among member states, and then of understanding such trends in relation to changes in industrial relations.

This leads us to discuss a number of policy issues in the conclusion (section 5), which are further explored in the national chapters in light of particular domestic contexts. 


\section{THE GOAL OF CONVERGENCE AS PART OF EU CONSTRUCTION}

Convergence was one basic objective behind the initial European Community construction and has motivated ever closer cooperation and integration.

The founders of the European Community had planned that common economic interests towards economic integration would drive more convergence in terms of living standards and then in terms of welfare states and social policies. Jean Monnet, in his address at the signing of the Treaty of Rome establishing the European Coal and Steel Community (ECSC) on 19 March 1951, emphasised:

The pooling of the production of coal and steel through the creation of a single market of 150 million consumers covering the territory of the six countries, in which all producers will have free and equal access to markets and all consumers a free and equal access to supplies will stimulate technical progress, the increase of productivity and the improvement of the standards of living. ${ }^{1}$

One of the aims of the Treaty of Rome in 1957 was precisely to reduce 'the differences existing between the various regions and the backwardness of the less favoured regions' and to promote 'harmonious development of economic activities, a continuous and balanced expansion, an increase in stability, an accelerated raising of the standard of living and closer relations between the States belonging to it' (Article 3).

'Convergence' was then complemented by the term 'cohesion' (economic, social and regional), which acquired a treaty basis in the 1986 Single European Act, and refers to the EU's ambition to reduce the gaps in development and wealth through a catching-up process and faster rates of growth for countries and regions at lower levels of development.

It is important, however, to highlight that such a convergence process at EU level was never seen as a convergence process that would tend towards parity. Even the Maastricht nominal convergence criteria, which put the concept of convergence at the core of the EU's and national member states' policy agendas, and applied it to macroeconomic indicators, did not require convergence to a single point, but towards a range with upper and lower bounds, which would accommodate differences among member states.

\subsection{European Community Tools Aimed at Ensuring Convergence and Coordination}

The European Community put in place a considerable number of European Community programmes, instruments and resources to facilitate this convergence and cohesion process, as reflected in the steady growth of structural and investment fund expenditure as a percentage of the EU budget. The European Charter of Fundamental Social Rights clearly enshrined social objectives as a common goal, while European structural funds were precisely aimed at promoting the convergence of less developed countries and of the most backward regions within those countries. It also led to a widening of the scope of the instruments, not least the Cohesion Fund targeted at member states with relatively low GDP (Treaty on European Union 1992) and to a significant increase in resources available for cohesion policy.

The European Community progressively extended the objective of convergence to other areas normally considered as being under national competence. Employment was first rec- 
ognised as a European policy goal at the Amsterdam Summit of 1997, before being placed in the core of the open method of coordination in the European Employment Strategy of 1998 and further confirmed in the Lisbon strategy in 2000 within the framework of the common leitmotiv 'for more and better jobs'. Although considered to be 'soft law' the open method of coordination - first applied to employment, then to retirement and social inclusion - did encourage national member states towards common goals, exchange of best practices among them and the implementation of National Action Plans monitored by the EC. The term 'coordination' is very close to the term 'convergence' and must be interpreted to mean using common objectives and common tools to facilitate convergence towards a number of common economic and social indicators across EU countries.

\subsection{Convergence a Priority in EU Enlargement Waves}

The various waves of EU accession, beyond their political goal of integration, were also aimed at bringing countries with a lower level of development (first the Southern European countries and then the Central and Eastern European countries) on to the road of convergence with EU economic and social standards.

The enlargement waves have increased the challenges facing cohesion policies. With the exception of Austria, Denmark, Sweden and the United Kingdom, all additions to the original six members of the EU had a GDP per capita below the EU average at the time of joining the group.

This ambition of convergence clearly represented a priority in the EU enlargements of the mid-2000s. Indeed, the enlargements of 2004 and 2007 were unprecedented, not only in terms of the number of new members, but also their relatively low level of GDP per capita. Accession to the EU was also considered by the candidate countries - then the new members of the EU - from Central and Eastern Europe, as well as Cyprus and Malta, as a lever for economic catch-up.

European Union accession was also accompanied by rapid growth in foreign investment, also seen as an engine of economic convergence. Beyond free trade within the EU, the freedoms of labour and capital associated with the EU are also expected to promote convergence based on comparative advantage, in accordance with the Heckscher-Ohlin model of international trade. The Solow model and neoclassical economics also predict upward pressure on wage growth in low-wage countries as foreign direct investment (FDI) moves inward, and downward wage pressure in relatively high-wage countries as investment moves towards lower wage areas, something that would be further enabled by free movement of workers and migration from low-income to high-income countries. In theory this may have the effect of encouraging trends of EU-wide convergence on wage levels, productivity and GDP per capita. This association between EU membership and convergence has been confirmed for the latest member states to join the EU, which have experienced spectacular growth. Various chapters in this book also show, however, that the convergence process has been limited in some EU countries, where the expected trends in accordance with the theory have not always been confirmed, with evidence of diversity within the EU. In this perspective it might be interesting to study whether withdrawal from the EU may lead to different catch-up paths, something that the chapter on the United Kingdom investigates by exploring its potential convergence performance after Brexit. 


\subsection{A Convergence Process Interrupted by the Crisis}

The severe economic crisis of 2007-08 seems to have interrupted what had hitherto been a process of convergence of standards of living among EU member states, something that becomes evident in the statistical analysis in section 4. The European convergence machine stalled, and in some cases even went into reverse, while the financial crisis and the threat to the euro revealed the need for stronger economic governance.

During this crisis period, the common goal of convergence somehow also disappeared from public policies and discourses, with national countries reacting to the crisis in very different and uncoordinated ways. Furthermore, the fiscal consolidation policies applied by the Troika - with the EC as part of it - in Greece, Portugal and Ireland led to adverse effects on a number of social indicators: as result, expected social changes that had been previously assumed as common goals among the EU28 suffered a setback, for example, expectations in terms of increased living standards, increased collective bargaining and the implementation of statutory minimum wage policies, among others. Besides the difficulties involved in overcoming the crisis, an understanding also emerged that the stability of the single currency required convergence on more than just the monetary and fiscal indicators adopted at Maastricht. 'It probably requires some prior convergence of labour market policies and characteristics' (EC 2017c). Thus, the aftermath of the financial and economic crisis, and the adverse effects left over in some of the most vulnerable economies among the EU28, has acted as the catalyst to put the convergence concept back at the centre of European policy discourse.

\subsection{The European Social Pillar: Signal of a Renewed Process of Convergence?}

In 2015, the Five Presidents' report, 'Completing Europe's Economic and Monetary Union', stated: 'the notion of convergence is at the heart of our Economic Union' (EC 2015). The objective of coordination and convergence was also re-emphasised in the Europe 2020 guidelines, which included common targets in terms of employment rates, social inclusion and education policies.

The term also gained other meanings and nuances, primarily in the context of governance of the Economic and Monetary Union (EMU). While the term 'convergence' was previously used in relation to monetary and fiscal indicators (as a prerequisite of a stable EMU), the trials of the euro in the early period of the financial crisis indicated that convergence on only these nominal indicators was not sufficient. The Five Presidents' report introduced in this context a greater focus on employment and social outcomes. It referred to 'structural convergence' and to the need for 'both more efficient labour and product markets and stronger public institutions' (EC 2015).

In 2017, the EC's launch of the European Pillar of Social Rights, a new flagship initiative then presented as a EC recommendation, represented an attempt to bring social policies back to the core of the policy agenda and to renew European coordination to further promote upward social convergence across the EU, 'designed as a compass for a renewed process of upward convergence towards better working and living conditions in Europe' (EC 2017d, p. 1). There are 20 principles and rights enshrined in the Pillar (including 'Social dialogue and involvement of workers') structured around three categories: (1) equal opportunities and access to the labour market; (2) fair working conditions; and (3) 
social protection and inclusion (EC 2017a). ${ }^{2}$ 'The logic of the Social Pillar more specifically is a social convergence logic of the economic governance of the EMU' (Eurofound 2017, p. 9).

\subsection{Industrial Relations to Serve the Convergence Process}

As emphasised by President Juncker, the EU needs to score 'a triple A on social issues'. ${ }^{3}$ In the same direction - and within this revitalisation of social policies - the EC set up a new 'Val Duchesse' round with European social partners to boost European social dialogue and to call for a more substantial involvement of social partners in EU policy-making and in new legislative initiatives. More emphasis was also given to capacity-building of social partners.

This socio-economic convergence is increasingly seen as necessary for both the stability of the single currency and before any further deepening of the integration process, not least in terms of fiscal governance. Such ex-ante social convergence before further development of the EMU is in marked contrast to the sequencing of the social dimension in the context of the advent of the 'single European market', when better social policy was expected to be the natural consequence of economic integration.

In light of such an ex-ante goal, it is important to understand how far countries have travelled in terms of converging with each other, or diverging, in matters of labour market and social outcomes, and the extent to which the financial crisis impacted on such a goal. This is precisely the objective of each of the chapters that make up this volume, in which national stories help to illustrate the social and economic dynamics in different European contexts. In the next section we summarise some of the most important messages of the national chapters in terms of the contributions of industrial relations to convergence. Complementing the national chapters, we offer some statistics on convergence trends and industrial relations in all EU28 member states.

\section{TYPES OF INDUSTRIAL RELATIONS EFFECTS ON CONVERGENCE: NATIONAL EXPERIENCES}

While studying convergence trends, the chapters in this volume provide concrete examples of how industrial relations may have contributed to convergence so far. Drawing on the experts' contributions in the five sub-sections below we highlight five ways through which industrial relations seem to have contributed to convergence of national stories.

\subsection{Role of Social Partners in National Policy Issues}

Several examples in this volume highlight the contribution of the negotiation and signature of tripartite national pacts to maintaining peace, while adjusting labour market conditions to the macroeconomic context. Industrial relations through such national social dialogue are found to have contributed to convergence.

The chapter on Belgium in this volume shows that the wage moderation on which the social partners have reached agreement has contributed to an increase in employment and to the development of the dual-earner household model, which has increased 
consumption and made it possible to achieve a number of macroeconomic goals. Various social dialogue mechanisms and institutions, such as extension mechanisms and indexation, have also helped in this. As shown by the author, this strong concertation model has led to real wage growth across the board and - together with extensive redistributive efforts, through both benefits and progressive taxes - helped Belgium in the end to achieve a more equitable spread of the benefits of economic growth than in many other rich EU economies.

Interestingly, as shown in this volume, the Netherlands, despite similarities with Belgium, has followed distinctly different trajectories: while the social partners have also embraced wage moderation, with an even greater effect on employment - and thus progress in terms of access to the labour market - this has often taken the form of part-time work and, more recently, temporary work, doubling its incidence, and growth in flexible and insecure contracts, with developing low-paid employment. This increase in temporary work - that according to the author the social partners have failed to contain - leads him to conclude that this became a clear case of divergence, as it has led the Netherlands away from the EU average, which increased only slightly.

By contrast, trade unions in Slovenia played a role in better regulating the use of nonstandard forms of employment. The chapter on Slovenia shows how they put the focus on this aspect rather than merely defending the established standard of regular employment. A common case study with Italy in this respect (appended to Chapter 7 on Italy) shows that, despite Italian trade unions' initiatives to improve the working conditions of non-standard forms of employment and notably temporary work, a lack of consultation with the social partners by the government led to less balanced outcomes.

Some wage moderation was also agreed by the social partners at macro level in Sweden in 2008-10 to preserve employment stability and limit increases in unemployment. Also, Sweden experienced the highest growth rate in Europe in 2014-17 and has performed better on many indicators of the European Social Pillar. This is explained by the author of the Swedish chapter in terms of a model of flexicurity that has allowed strong external flexibility, while strengthening workers' employability through a national training system in which the social partners are directly involved, as well as ensuring high wages and working conditions. Social protection, in which the social partners are also involved, has also remained a strong asset as regards maintaining Sweden's good record in terms of social and economic indicators.

Similar wage moderation was agreed through a series of social pacts in Ireland that also contributed to economic growth and social peace in the early $2000 \mathrm{~s}$. The chapter on Ireland in this volume highlights that convergence was to some extent halted during the crisis years when they had to implement a strong fiscal consolidation policy. However, Ireland also experienced a very rapid economic recovery. The author highlights that social dialogue may have contributed to this. In fact, the series of agreements after 2009, after some interruption of tripartite social dialogue in the crisis years, does nevertheless represent a degree of continuity in social dialogue and illustrates the utility of maintaining social dialogue as a problem-solving response to economic crisis. These agreements have led to some pay cuts and reductions in public sector employment, as well as reforms in work practices and redeployment, but have also helped to provide job security for public sector workers on permanent contracts. They also provided for pay restoration when macroeconomic and fiscal conditions improved. This would help to explain why 
Ireland managed to reduce inequalities, thus diverging in a positive manner from the average of the EU, where inequalities increased gradually between 2007 and 2016.

The social partners have also played a prominent role in the regulation of the French labour market, especially in the determination of wages (that have remained dynamic in France even through the crisis) and the application of social rights for workers. They have directly contributed to maintaining high levels of protection through unemployment insurance and to developing new rights (such as accounts and compensation for 'arduous work', which play an important role in a period of retirement reforms). The French chapter also explains how industrial relations have helped older workers' employment as well as gender equality, and how these different forms of involvement have contributed to social convergence.

Industrial relations are also found to have contributed to the catching up and social and economic convergence processes of southern European countries in the 1970s and 1980s, when they were initially less advanced, by providing the necessary context for stimulating the labour market, creating a more favourable environment in the workplace and contributing to a fairer distribution of income, as well as by promoting stable prices, notably through social pacts. One major feature of the Spanish story in this volume is the lack of convergence in social expenditure, which, since the mid-1990s, has remained stagnant as a share of GDP during more than a decade of high GDP and employment growth - social convergence being somehow decoupled from economic growth - and led to an anaemic welfare state. As a result, increased inequality and poverty in Spain could be explained by this lack of growth in social expenditure. In such a context of social spending stagnation, the trade unions in Spain, within a larger campaign on social protection, contributed to some important improvements made in recent decades, such as the creation of a system of non-contributory universal pensions for retirees with no access to standard contributory retirement pensions in 1990, or, more recently, to the successful promotion, during the crisis, of an extension of unemployment assistance for the long-term unemployed without unemployment benefit protection. They have recently been deeply engaged in the debate on the need for a guaranteed minimum income to fight poverty.

Similarly in Portugal, important agreements between the social partners have allowed several reforms of labour law, but also social recognition of the need to tackle certain structural deficits in the Portuguese labour market. The chapter on Portugal shows that they notably agreed on key directions for convergence, such as the need to go beyond competition based on low wages, the recognition of skill shortages and the need to invest in both education and training, and to maintain a healthy social security system. They were present in the recent public debate on the issues of ageing and fertility, and worked together to promote gender equality and reconciliation of work and family life.

The involvement of the social partners was found to be more limited in the Baltic states and thus to exert less of an influence on social and economic outcomes. Industrial relations around minimum-wage fixing, however, seems to have played a role in limiting the growth of inequalities in Estonia. The involvement of the social partners as regards the minimum wage was also found to be determinant in a number of other EU countries (Ireland, Slovenia and Germany).

The role of the social partners is not limited to the regulation of the labour market strictly speaking, but can extend to influence other national policy issues. For instance, 
trade unions in Slovenia, which are involved in tripartite debates, managed to counter the plan for a flat-rate tax in the mid-2000s, which might have had adverse implications on equality and convergence towards better inequality outcomes. ${ }^{4}$

Some chapters in this volume show that industrial relations (notably through social partners' involvement in national policies) can help to improve education. In Sweden the social partners have helped to promote occupational mobility policies and the development of skills over the life course, with constant skills upgrading and a low percentage of low-paid workers. As a result, Sweden today has the highest levels of job quality in the EU (see details in the chapter on Sweden in this volume). In France, social partners are also directly involved in the definition and management of lifelong learning, while job quality is officially among the goals of some trade unions (see the chapter on France in this volume). There is also a statutory obligation to have some collective bargaining on the quality of working life (every four years). At EU level, the European Trade Union Confederation (ETUC) has also formulated clear goals with regard to job quality.

The story of the United Kingdom is also interesting, showing in terms of convergence that the country has been excellent on certain indicators, such as access to the labour market, and thus has been performing as a good job-generating machine, but with more modest results in terms of delivering decent work (as defined by the International Labour Organization) for all, especially for women. This situation is explained in part by its weak mechanisms and structures for social dialogue, and partly because trade unions do not play a substantive role in designing and shaping economic, social or labour market policy. This institutional context is expected, according to the author, to be further diluted after Brexit. The case study in the UK chapter also shows that the social partners have been involved, for instance, in campaigns against bogus self-employment at national and sectoral level notably in the logistics and transport sectors - but that the gains of such campaigns have not been widely diffused because of an erosion of social dialogue institutions.

\subsection{Value-added Provided by Collective Agreements}

In Sweden, the bipartite nature of some labour market regulations, coupled with high union density and a high coverage rate of collective bargaining, have created a favourable institutional environment for the emergence of negotiated compromises aimed at balancing flexibility and security in the labour market, as stressed by the chapter on Sweden. This has led to innovative arrangements on wages, flexible working hours and vocational training at both industry and enterprise level. Sweden is also one of the few EU countries which has experienced an increase (by 3 per cent) in the labour share of GDP between 1993 and 2015, in contrast with most other EU countries, in which the labour share has declined continuously.

There are examples of collective agreements at industry or enterprise level that have extended and improved the statutory universal basic protection in the form of higher replacement/compensation rates over a longer period of entitlement, for example regarding unemployment and sickness benefits, parental and training leaves and pensions (occupational pensions).

Lifelong learning schemes, or arrangements, and working time accounts decided by collective bargaining have also contributed to enabling the upgrading of skills and increasing opportunities for women and young people in Sweden, something that is also 
being attempted now in France. In Germany, innovative agreements have been concluded by the social partners allowing a more variable distribution of working time over the year and through the various phases of working life, which has contributed to the flexibility required for employment, growth and convergence. Many collective agreements have also reduced the level of overtime in order to make jobs available for younger people, particularly trainees, thus also responding to youth unemployment.

The chapter on Portugal highlights how the social partners have started to negotiate a number of collective agreements that include arrangements to reconcile work and family life; by this means, among other things, they hope to contribute to the national goal of increasing fertility rates.

Similarly in Spain, industrial relations, with an automatic extension of collective agreements and wide collective agreement coverage, even in a context of low trade union density, have certainly contributed to limit wage inequality before the crisis hit (see the chapter on Spain in this volume).

In Ireland, the resumption of collective bargaining across most of the public sector, and the development of pattern bargaining in the private sector in the context of economic recovery, suggests some continuity, and a degree of coordination in social dialogue.

\subsection{Convergence as a Benchmark for Collective Bargaining}

Collective agreements in some EU countries define wage increases based on monitoring wage-setting practices in neighbouring countries. An interesting example is the Belgian framework, introduced in 1996 to preserve the country's competitiveness in the EMU by keeping wage development in line with its main trading partners. A national body regularly reports on the evolution of Belgian competitiveness relative to its main trading partners, such as the Netherlands and Luxembourg. These reports are used by the social partners to fix a wage norm for the next round of wage negotiations. Although the norm is only a non-binding guideline, it has generally been respected. The system seems to have worked fairly well: it has kept untouched the wage formation and bargaining system that existed prior to euro accession, but has made the behaviour of the social partners compatible with membership of the euro area (Sapir and Wolff 2015).

While the Belgian system cannot be exactly duplicated by other euro-area countries because they have different wage formation and bargaining systems, all euro-area countries could establish a mechanism to ensure that, although operating within their own system, the behaviour of the social partners and the outcome of their wage negotiations would be compatible with euro-area membership in terms of competitiveness and employment.

In June 2015, the Five Presidents' Report followed up on this idea and proposed to set up a euro-area system of competitiveness authorities. As a follow-up to the report, in October 2015 the Council adopted a Recommendation requiring euro-area member states to establish national competitiveness boards. This process might be more effective, however, if tackled with the social partners. It could also be extended to countries outside the euro area to facilitate convergence within the larger EU.

Similar to Belgium, in Ireland in 2011 the Services Industrial Professional and Technical Union (SIPTU) agreed a modest pay rise of 2 per cent directly with the relevant companies, in a so-called ' 2 per cent strategy' that took into account wage rises 
in Germany as well as the European Central Bank target of 2 per cent inflation. By 2014, the ' 2 per cent strategy' had delivered over 220 collective agreements, covering more than 50000 workers (see the chapter on Ireland in this volume). These two examples directly show how industrial relations can help in regulating wages and thus also employment to achieve convergence. This requires that institutions that monitor competitiveness be embedded in social dialogue and that distributive concerns be mainstreamed in the monitoring of competitiveness (Vandenbroucke 2017).

To better contribute to convergence, industrial relations should also be able to operate across borders through, for instance, International Framework Agreements (IFAs). While such IFAs have focused mainly on relocations and redundancies, more studies should be carried out to measure their potential impact on convergence. While the monetary union calls for integrated competitive markets for goods and services and cross-border mobility of labour, this in turn entails a social corollary. In this respect, international framework agreements (Papadakis 2011) and also European works councils (De Spiegelaere and Jagodzinski 2015) have been shown to contribute to convergence, or at least to avoid divergence in working conditions.

\subsection{Industrial Relations as a Factor of Resilience}

The chapters in this volume also provide examples of industrial relations' role in inducing a more balanced sharing of the costs of the crisis for both working conditions and inequalities at work. In Sweden, the social partners developed innovative practices and solutions in the 1990s to deal with job losses and structural changes. Agreements covering three-quarters of the labour force have been negotiated to help victims of restructuring to find new jobs rapidly. In Ireland, the Haddington Road Agreement (2013-18) included pay cuts, but also provided for the restoration of these pay cuts in 2016. The agreement also led to some flexibility to allow for redeployment, work-sharing arrangements and workforce restructuring (see chapter on Ireland in this volume). In Germany, the negotiation of collective agreements on reduced working hours has also made it possible to avoid employment cuts. In part as a result of these different adjustment mechanisms negotiated through social dialogue, these countries (with the possible exception of Ireland, where unemployment increased from 4.7 per cent in 2006 to 14.7 per cent in 2012) have experienced only very modest increases in unemployment during the recession. By contrast, in countries where the low presence of trade unions and a lack of social dialogue impeded the pursuit of such mechanisms, as in the three Baltic states, the bulk of adjustments have involved employment cuts, with a very rapid increase in unemployment rates.

\subsection{Extending the Role of the Social Partners to New Issues}

The various chapters of this volume show how industrial relations help, notably through collective agreements, to better regulate the increase in non-standard forms of employment. The case study comparing the Belgian and Dutch experiences shows how a stronger role for the social partners and more formal institutions of social dialogue have allowed Belgium to limit the growth of temporary contracts - which affect 9 per cent of Belgian employees compared with 20 per cent of Dutch employees - and the association of temporary contracts with part-time work. Similarly, the resilience of trade union membership 
in Belgium (it has been eroded in the Netherlands) and the fact that it is distributed more equally among the population - for instance, Belgian women have a union density three times higher than in the Netherlands - have probably contributed to a very low gender pay gap (3.3 per cent), only a quarter of the gender pay gap in the Netherlands. Women are also more likely to be the main earner in a household in Belgium than in the Netherlands. Women's access to more employment and to better wages is important for boosting the dual-earner model and for the growth and stability of the middle class, with all the implications of this for social and economic convergence (at EU level, see Vaughan-Whitehead 2016). The social partners should also certainly investigate how to improve coverage and protection of young workers. The chapter on Ireland suggests that it may have started to diverge from Europe because its young people have been particularly badly affected and young workers are subjected to low employment standards.

The case studies in this volume analyse how the scope of industrial relations could be extended to other important areas, such as migration and FDI, which may influence both social and economic convergence (see Table 1.1). For example, in Sweden collective agreements on work practices/work experience schemes and Vocational Introduction Employment have targeted young newly arrived migrants lacking relevant experience. Similarly, the case study in the Spanish chapter shows how trade unions in Spain have, from the beginning, embraced the integration of immigrants and contributed to promoting their equal treatment in terms of integration and working conditions.

Various chapters in this volume highlight the importance of inter-EU migration and migration into the EU from a number of perspectives. The chapter on the Baltic states, for instance, presents evidence of how emigration may be problematic for convergence but that there can also be benefits from return migration or even from inward migration from further east. The example of emigration of medical professionals, such as doctors, is often reported as particularly illustrative. In this respect, 'return mobility' may be considered a key factor in convergence (see, for example, the EC's report on intra-EU mobility; EC 2018). The chapters on Italy and Spain also refer to the effects within the labour market of migration into the country from outside the EU, noting that both these countries have moved from a position of relative stability in migration flows (or historical outflows in the case of Italy) to one of substantial net inflows. The chapter on Ireland also refers to the balance between the 'exit' and 'voice' of young workers as a prism though which to judge the health of the Irish economy. It is clear, therefore, that the issue of migration is important in a number of countries in the EU in terms of its labour market effects and hence prospects for convergence, and that the social partners certainly have a key contribution to make in this area.

\section{CONVERGENCE, THE EUROPEAN PILLAR OF SOCIAL RIGHTS AND INDUSTRIAL RELATIONS}

So far this chapter has explained how the various national stories included in this volume assess the possible role of industrial relations in explaining some of the dynamics of social indicators. Whereas the individual chapters provide national analyses, the European Pillar of Social Rights (EPSR), as one of five key policy areas of the European Union, calls for building a more inclusive and fair EU where all member states come 


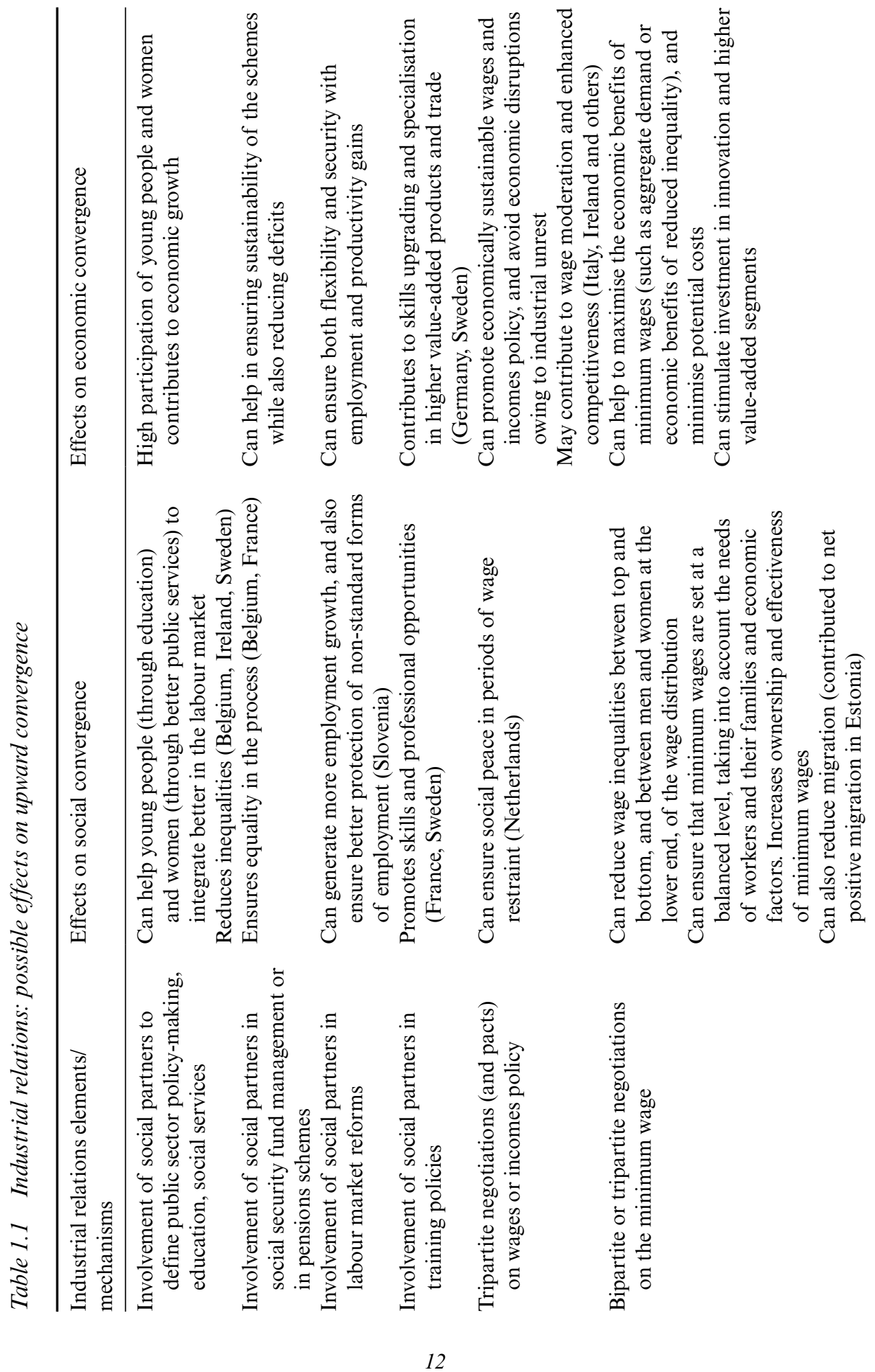



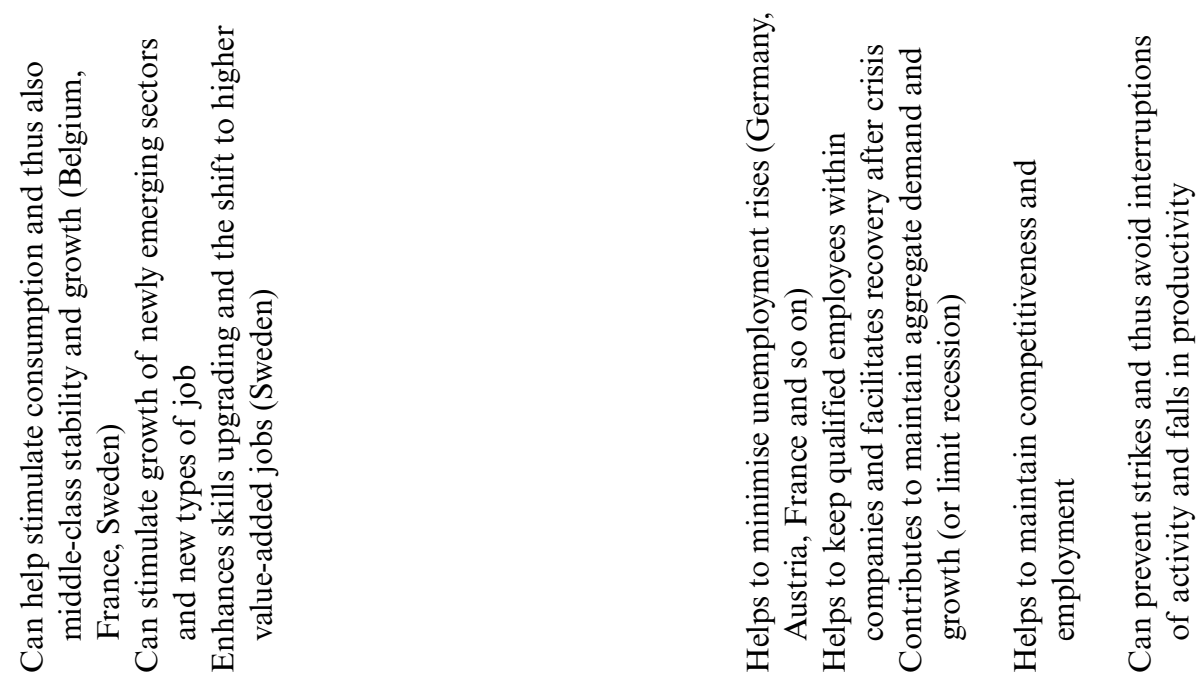

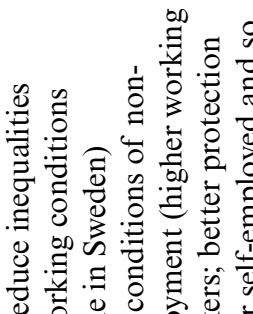

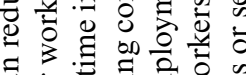

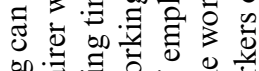

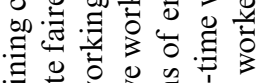

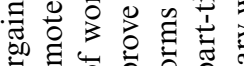

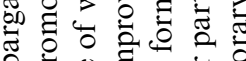

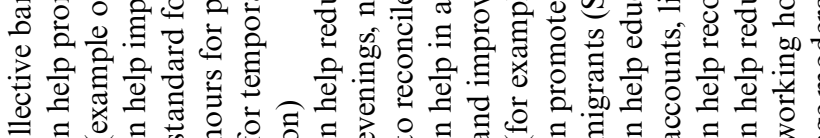

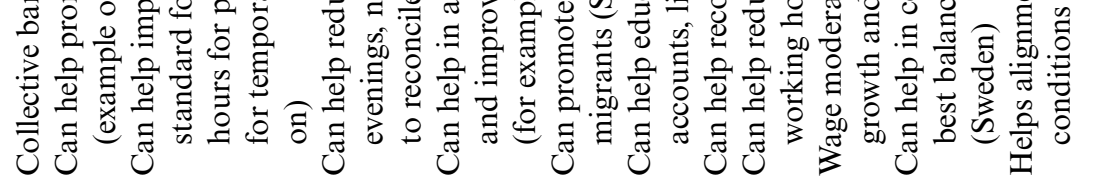

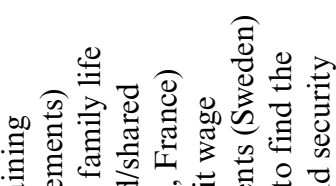

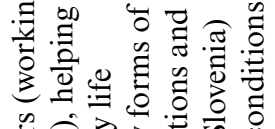

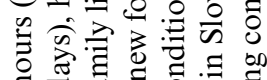

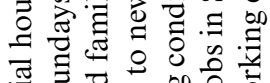

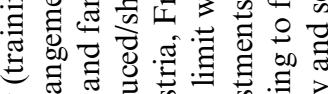

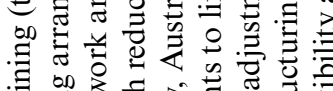

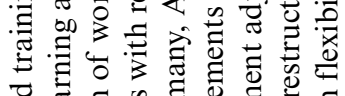
tे 引

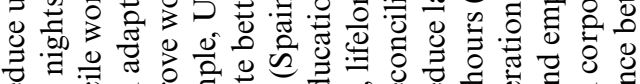
0 8

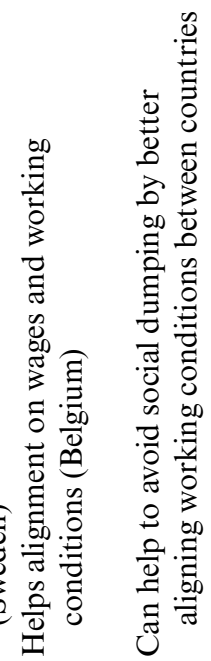

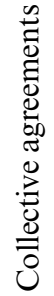
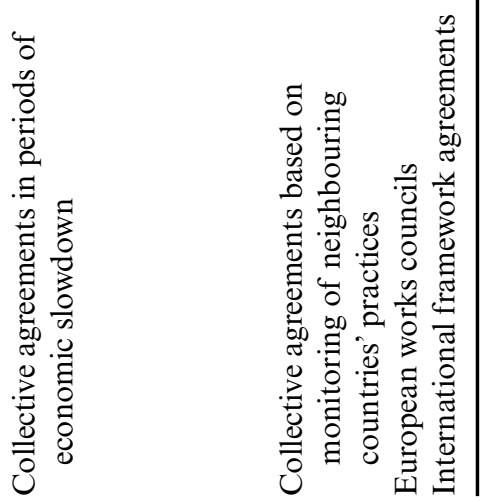
closer (or converge) on a set of 20 principles and rights. ${ }^{5}$ Based on this call, a natural question to ask is how far apart, or close together, the 28 member states currently are with regard to achieving these 20 principles and rights? In this volume the focus is on the sub-set of these principles and rights that have a direct bearing on the labour market and related socio-economic and institutional outcomes. Moreover, and as highlighted by the national chapters, industrial relations play a key role in the pursuit of common goals and therefore the question naturally arises, what has been the role of industrial relations in the current status of EU28 member states in matters of the labour market and related socio-economic outcomes?

\subsection{How Has Convergence Been Defined?}

Convergence is by definition a long-term phenomenon, despite the fact that economic picks and throws can identify convergence and divergence from some desired goal within short periods of time. ${ }^{6}$ In the analysis that follows, convergence is measured over a 17-year period, from 2000 to 2016 . In the case of the EU, and given its relatively short history as a unified group, this 17 -year period can be considered indicative of convergence in socio-economic outcomes. This is because the period takes into consideration the waves of accession years and covers the pre- and post-financial crisis periods, thus allowing us to capture how it impacted on the aggregate dynamics of the current EU28 member states. Most of the other chapters in this volume rely on additional national statistics and cover a period from 1990 or earlier.

Discussions within the group of experts led to a definition of convergence on the basis of two main criteria. First, since the aim of the EU is to improve the economies and wellbeing of the population, our group of experts defined convergence as a trend towards an improvement of socio-economic indicators. This means that, over time, the average of the EU should improve in tandem with the progress of individual countries. This does not mean, however, that countries should have as a target to maximise or minimise all indicators, given the different nature of the indicators (Table 1.2 develops this point further).

\section{Table 1.2 Convergence scenarios in the EU}

\begin{tabular}{lll}
\hline & $\begin{array}{l}\text { Progress on socio-economic indicators } \\
\text { (EU average increases) }\end{array}$ & $\begin{array}{l}\text { Deterioration in socio-economic } \\
\text { indicators (EU average decreases) }\end{array}$ \\
\hline $\begin{array}{l}\text { Convergence } \\
\text { (lower dispersion) }\end{array}$ & $\begin{array}{l}\text { Scenario 1: Upward convergence } \\
\text { Progress of all countries with less } \\
\text { advanced countries also catching up }\end{array}$ & $\begin{array}{c}\text { Scenario 4: Downward } \\
\text { convergence } \\
\text { All countries may evolve together } \\
\text { towards a deterioration of their } \\
\text { indicators }\end{array}$ \\
\hline $\begin{array}{l}\text { Divergence } \\
\text { (higher dispersion) }\end{array}$ & $\begin{array}{c}\text { Scenario 2: Upward divergence } \\
\text { (dispersion alongside increased } \\
\text { performance) }\end{array}$ & $\begin{array}{c}\text { Scenario 3: Downward divergence } \\
\text { (dispersion alongside decreased } \\
\text { Progress of all countries on indicators } \\
\text { but some countries continue to } \\
\text { progress more quickly than others }\end{array}$ \\
& $\begin{array}{l}\text { Dispersion because some may } \\
\text { evolve towards a deterioration } \\
\text { while the others progress or } \\
\text { remain stable }\end{array}$ \\
& &
\end{tabular}


Within this upward movement, convergence also implies a catching-up process of less advanced countries on those indicators, allowing them to get closer to the average and also somehow closer to the best performers.

The second main feature in our definition of convergence is a lower dispersion among EU countries, while divergence would represent an increased dispersion.

Convergence and divergence movements can be classified in one of four possible scenarios, as described in Table 1.2. In this table, both convergence and divergence can be upwards or downwards. Upwards (downwards) convergence occurs when the values of the indicator are coming together and, on average, each country is doing better (worse) than in previous periods; under such circumstances we would observe the EU28 average increasing (decreasing). Upwards (downwards) divergence occurs when the values of the indicator are moving apart, with some countries scoring higher (lower) values compared with the rest - and with previous periods - and above (below) the EU28 average.

The optimal scenario represents all EU countries experiencing a lower dispersion and also improving on their socio-economic indicators with all countries attaining a better outcome in their labour market and social indicators. In this case the overall EU average would increase (scenario 1 in Table 1.2).

The achievement of social cohesion as desired by the EPSR would be associated with this upwards convergence scenario. Such movement would reflect that all EU28 countries are, in tandem, following a positive path, where countries with weaker outcomes in terms of labour and social indicators are improving compared with previous periods and at a faster rate, while countries already exhibiting good labour market and social outcomes continue to do well or even better than in previous periods. In Table 1.2, upward convergence is described in the top-left quadrant (scenario 1). The other three scenarios in the table show possibilities that gradually move away from the preferred upwards convergence outcome.

There could be a second possible scenario, with all countries also improving on socioeconomic indicators (with then also an increase in the group average), but leading not to a lower but to an increased dispersion because certain countries continue to progress more quickly than others (scenario 2).

Although less desirable than scenario 1, this last outcome would still be more beneficial for all countries than a scenario that involved increased dispersion, alongside a general deterioration of socio-economic indicators, thus leading to a decrease in the EU average (scenario 3). In this case, some or all countries are experiencing a weakening of the underlying labour and social indicators, while the difference between the countries with lower outcomes (for example, a higher unemployment rate and lower social protection spending) moves further apart from countries experiencing relatively better outcomes.

Another possible case would be convergence between EU countries, not towards an improvement, but towards a deterioration of socio-economic indicators, which would imply a decrease in the EU average (scenario 4).

\subsection{Overview of Convergence Using a Selection of Indicators}

One way to answer the above questions is with a comparative analysis of the 28 countries using a selection of indicators that capture the principles and rights of the EPSR in relation to labour market outcomes and industrial relations. An inspection of the 20 
principles endorsed by the EPSR helps in the selection of indicators to measure the three dimensions targeted by the 20 principles: opportunities and access to labour markets, fair working conditions, and inequality and social protection. Table 1.3 reflects these general dimensions and principles defined by the EC and proposes a list of corresponding statistical indicators to capture them, all of which are consistent with the indicators used

Table 1.3 Indicators covering the areas of principles and rights underlined by the

European Pillar of Social Rights, by dimensions, as structured by the European Commission

\begin{tabular}{|c|c|c|c|}
\hline Dimensions & Areas & Least controversial indicators & $\begin{array}{l}\text { Most controversial } \\
\text { indicators }\end{array}$ \\
\hline \multirow{5}{*}{$\begin{array}{l}\text { 1. Equal } \\
\text { opportunities } \\
\text { and access to } \\
\text { labour market }\end{array}$} & Access to & Employment rate & \\
\hline & labour & Unemployment rate & \\
\hline & market & Youth unemployment rate & \\
\hline & & Long-term unemployment rate & \\
\hline & $\begin{array}{l}\text { Opportunities } \\
\text { in the labour } \\
\text { market }\end{array}$ & $\begin{array}{l}\text { Participation in training (at } \\
\text { least in the past four } \\
\text { weeks) as a percentage } \\
\text { of dependent workers: if } \\
\text { level of education is below } \\
\text { secondary; if level of } \\
\text { education is secondary; if } \\
\text { level of education is higher } \\
\text { than secondary }\end{array}$ & \\
\hline \multirow[t]{2}{*}{$\begin{array}{l}\text { 2. Fair working } \\
\text { conditions }\end{array}$} & Wages & $\begin{array}{l}\text { Wage in } 2011 \text { PPP constant } \\
\text { values; growth in average } \\
\text { wages of full-time employees }\end{array}$ & $\begin{array}{l}\text { Kaitz Index (minimum } \\
\text { wages as proportion of } \\
\text { average wage) }\end{array}$ \\
\hline & $\begin{array}{l}\text { Employment } \\
\text { contract }\end{array}$ & $\begin{array}{l}\text { Involuntary part-time among } \\
\text { all part-time employment }\end{array}$ & $\begin{array}{l}\text { Proportion of workforce } \\
\text { with temporary } \\
\text { contracts }\end{array}$ \\
\hline $\begin{array}{l}\text { 3. Social } \\
\text { protection } \\
\text { and inclusion }\end{array}$ & $\begin{array}{l}\text { Social } \\
\quad \text { protection }\end{array}$ & & $\begin{array}{l}\text { Per capita spending on } \\
\text { social protection }\end{array}$ \\
\hline \multirow[t]{2}{*}{$\begin{array}{l}\text { 4. Economic } \\
\text { performance } \\
\text { and } \\
\text { distributional } \\
\text { outcomes }\end{array}$} & Inequality & & $\begin{array}{l}\text { Share of household } \\
\text { income in the D1 } \\
\text { decile; and of } \\
\text { household income in } \\
\text { the D10 decile; ratio } \\
\text { between total share } \\
\text { of household income } \\
\text { in D2 to D4 deciles } \\
\text { to total share of } \\
\text { household income in } \\
\text { the D5 to D9 deciles }\end{array}$ \\
\hline & $\begin{array}{l}\text { Economic } \\
\text { performance }\end{array}$ & $\begin{array}{l}\text { GPD per capita growth (from } \\
\text { GDP in constant } 2011 \text { PPP } \\
\text { values) }\end{array}$ & Labour income shares \\
\hline
\end{tabular}


in the national chapters presented in this volume. A review of the national chapters would suggest adding a fourth dimension to capture 'economic performance and redistribution'. Table 1.3 shows selected indicators that could in principle be compared to shed light on whether the EU28 is converging or diverging with respect to social and economic dimensions proposed by the EPSR. Table 1A.1 in the Appendix to this chapter provides more details on each of the indicators.

The proposal of a comparative analysis of the 28 countries raises two problems: first, jointly analysing the common indicators presented in Table 1.3 is a complex task and potentially misleading if the purpose is to understand overall convergence or divergence among the EU28. The second problem is that of making a value judgement on the direction that each indicator in Table 1.3 would have to follow in pursuit of convergence among member states while 'delivering new and more effective rights for citizens' - which is what the EPSR prescribes. To highlight this, Table 1.3 classifies the indicators in two columns: least controversial and most controversial. For example, it is not controversial to think that member states all aim at the lowest possible unemployment rate, so we could conclude there is positive convergence in matters of unemployment between the EU28 if we observe that over some period of time these countries are, on average, moving together (converging) towards lower unemployment rates. This would be an example of upwards convergence that hints at social improvement for Europe's citizens. On the other hand, it would not only be controversial but also undesirable to prescribe that countries follow policies of 100 per cent permanent contracts, even if such hypothetical movement, from a quantitative point of view, was also associated with upward movement (convergence) among the EU28.

Despite the two above-mentioned problems, coming up with a monitoring and evaluation tool that checks for EU28 convergence under the EPSR remains a potentially desirable goal: the tool would highlight the objectives pursued by the EPSR while helping policy-makers to make timely and objective assessments of the direction taken by the pursuance of common goals. Meanwhile, and considering that the work in this volume attempts to convey a message for the EU28, it is reasonable to explore quantitative tools that could summarise information available for all 28 economies, over a period of time sufficient for capturing convergence, and in light of the goals implied by the EPSR. This consideration is what drives us to finish this chapter with estimates from a summary measure constructed with the indicators representing the EU28 EPSR; the summary measure is presented not as an ultimate instrument, but to show the potential of such a monitoring tool. Ultimately, the summary measure is also informative in this context because it provides information from countries in the EU28 that are not present in the national chapters.

The measure proposed implies a unification of the 20 indicators proposed in Table 1.3 under a single metric, therefore reducing a 20-dimension analysis into a singledimension analysis: this already takes care of the first problem mentioned above. We call this summary measure a Labour and Social Summary Indicator (LSSI). The technique employed for the purpose is a slight modification of other summary measures, such as the Human Development Index (HDI, of the United Nations Development Programme) or the Better Life Index (BLI, of the Organisation for Economic Co-operation and Development). The proposed measure leads to a summary value that helps us to easily inspect convergence (or divergence) among the EU28 member states with regard to the 
Table 1.4 Mapping of EU28 countries according to values of LSSI in 2016 and changes in LSSI between 2000 and 2016 (median wage based on unweighted value)

\begin{tabular}{|c|c|c|}
\hline & $\begin{array}{l}\text { Increase in value of LSSI } \\
\text { between } 2000 \text { and } 2016\end{array}$ & $\begin{array}{l}\text { Decrease in value of LSSI } \\
\text { between } 2000 \text { and } 2016\end{array}$ \\
\hline $\begin{array}{l}\text { Countries with LSSI score in } 2016 \\
\text { above or at the medium value of the } \\
\text { EU28 score in } 2016\end{array}$ & $\begin{array}{l}\text { Austria } \\
\text { Belgium } \\
\text { Czech Republic } \\
\text { Denmark } \\
\text { Finland } \\
\text { France } \\
\text { Germany } \\
\text { Luxembourg } \\
\text { Malta } \\
\text { Slovenia } \\
\text { Sweden }\end{array}$ & $\begin{array}{l}\text { Ireland } \\
\text { The Netherlands } \\
\text { United Kingdom } \\
\text { EU28 }\end{array}$ \\
\hline $\begin{array}{l}\text { Countries with LSSI score in } 2016 \\
\text { below the medium value for the } \\
\text { EU28 score in } 2016\end{array}$ & $\begin{array}{l}\text { Bulgaria } \\
\text { Estonia } \\
\text { Hungary } \\
\text { Latvia } \\
\text { Lithuania } \\
\text { Slovakia }\end{array}$ & $\begin{array}{l}\text { Croatia } \\
\text { Cyprus } \\
\text { Greece } \\
\text { Italy } \\
\text { Poland } \\
\text { Portugal } \\
\text { Romania } \\
\text { Spain }\end{array}$ \\
\hline
\end{tabular}

underlying indicators described in Table 1.3. Appendix 1A.2 provides the details leading to the LSSI.

Using the LSSI, the EU28 can be classified into four groups based on a combination of the following two outcomes: (1) whether their LSSI value is higher or lower than the EU28 median in 2016, and (2) whether their LSSI value increased or decreased between 2000 and 2016. This provides the mapping of the EU28 countries presented in Table 1.4.

We further investigated this issue through a more in-depth analysis of convergence that consisted of plotting the distribution of the estimated LSSI over time.

Figure 1.1 shows changes in the distribution of LSSI measured for each of the EU28 countries for the period 2000 to 2016: a few years have been selected for clarity of illustration. The distribution of the LSSI for each selected year has been summarised into a box-plot, a simple device that highlights the median of the distribution (the thick horizontal line inside the rectangles), the twenty-fifth and the seventy-fifth percentiles of the LSSI distribution (the edges of the rectangles), the extremes (upper and lower lines) and outliers (dots). A vertical stretching or shrinking of the rectangle shows (respectively) divergence or convergence among the LSSI values (that is, among the EU28) over subsequent periods of time, while an increase or a decrease of the median values over time (within those rectangles) shows (respectively) an upward or a downward movement of the values of the LSSI.

According to these measurement criteria, the dynamics of the box-plots over the period 2000 to 2016 show three clear periods. In the first period, prior to the global 


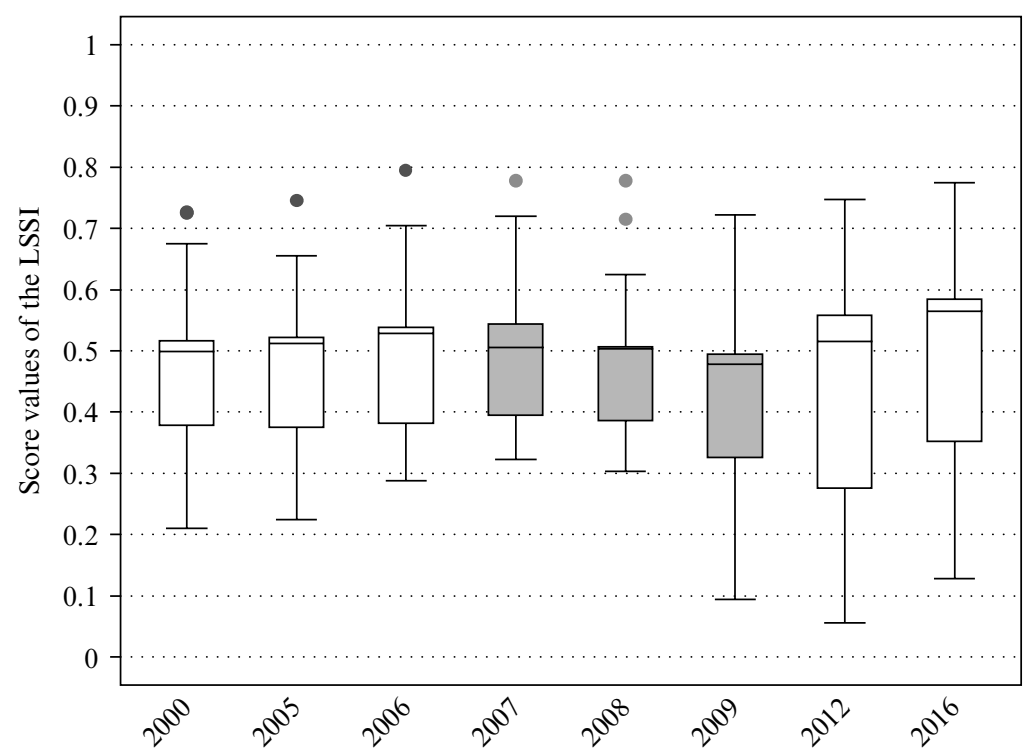

Note: The years in grey are the crisis years. The figures show the weighted distribution of the LSSI for the EU28.

Source: International Labour Organization (ILO) estimates.

Figure 1.1 Changes in the distribution of the Labour and Social Summary Indicator (LSSI) over time, EU28, 2000-2016 (selected years)

financial crisis, the EU28 was moving towards convergence in matters underlying the EPSR, as captured by the LSSI with a higher median in the boxes showing higher values of the LSSI positively affecting more individuals in the EU28 countries and more concentration (smaller boxes showing lower dispersion) of the values. This could be described as a situation of upward convergence (or scenario 1) among the EU28.

In the second period, during the financial crisis (2007-10), the positive convergence achieved just before the crisis was lost by the time countries were coming out of the crisis after 2009: the LSSI shows a downward movement so that on aggregate it seems that the EU28 had declined in terms of the value of the indicators that underline the EPSR. The value of the LSSI had also widened significantly compared with the year 2000 or compared with immediately prior to the crisis. In 2009 countries were moving apart from each other, with the distribution of the LSSI in that year widening in both directions compared with previous periods (downward divergence or scenario 3).

The third period starts in the aftermath of the crisis; comparing 2009 with 2012 shows that divergence among the EU28 countries has continued in the two directions: countries resilient to the crisis in terms of the indicators underlying the EPSR continued to improve in the years leading up to 2012, while in the same period countries below the median continued to decline. The LSSI in 2016 shows a slightly higher value compared with 2012, but over the four years the movement was marginal, while catching up to the levels 
of convergence observed in 2006 was yet to be achieved (higher box). The distribution in 2016 shows a clear divergence between countries above and below the median, especially when compared with the distribution of the LSSI in 2000 (scenario 3 type of downward divergence).

Putting all this in numerical terms, and excluding outliers, the (weighted) variance among the values of the index in 2005 was estimated at 0.012; in 2012 this had increased to 0.021 , that is, by 75 per cent. In 2016 the variance had declined to 0.018 but this is still 50 per cent more than the variance in 2005 , when countries showed more convergence in their performance with regard to labour market and social dynamics. ${ }^{7}$

In summary, these results show that there was convergence before the crisis, which was then interrupted by the crisis, after which more dispersion prevailed. We observe a longterm divergence, rather than convergence, between 2000 and 2016.

\subsection{What is the Relationship between Industrial Relations and Convergence?}

Union density and collective bargaining coverage are two indicators often considered to reflect the outcome of industrial relations institutions, for example, the outcome of multiemployer bargaining processes, extension mechanisms or tripartite pacts and agreements, to mention only a few. In this volume the national chapters highlight the importance of industrial relations for strengthening labour market and social dynamics, with evidence and data from each of the individual countries and from the various case studies.

The question is, to what extent can the evidence from the LSSI, in view of the evolution of industrial relations, provide further backing for the national stories, and evidence for the aggregate EU28? We start by examining the relationship between collective bargaining and union density to understand the complementarity between these two variables in capturing the evolution of industrial relations among the EU28 member states. Figure 1.2 compares the relationship between collective bargaining coverage and union density in 2016, and Figure 1.3 shows the relationship between changes in collective bargaining coverage and changes in union density during the past 17 years (2000-2016).

In particular, Figure 1.2 shows a strong relationship between the two outcomes, suggesting that both union density and collective bargaining coverage probably result from the same enablers of industrial relations at country level. Thus, countries that have strong coverage are also those with strong union density (for example, Scandinavian countries, Belgium, Malta, Cyprus, Italy and Luxembourg), whereas countries with low coverage are associated with low unionisation (for example, Estonia, Latvia, Lithuania or Bulgaria). There are some outliers that show strong collective bargaining coverage (for example, France and Austria), but relatively low levels of unionisation. However, the evidence for the opposite case is weak, that is, we do not see countries with high union density similar to Scandinavian unions that, at the same time, have weak collective bargaining coverage. Thus, despite a few outliers - with France serving as an example, mostly owing to its industrial relations institutions and practices - a correlation coefficient of 49.3 would suggest that collective bargaining is seemingly related to union density, and where the latter is high the tendency is to have higher levels of collective bargaining coverage.

At the bottom-left of the Figure 1.2 is a group of countries that has very low collective bargaining coverage and trade unionisation, including the three Baltic states (Estonia, 


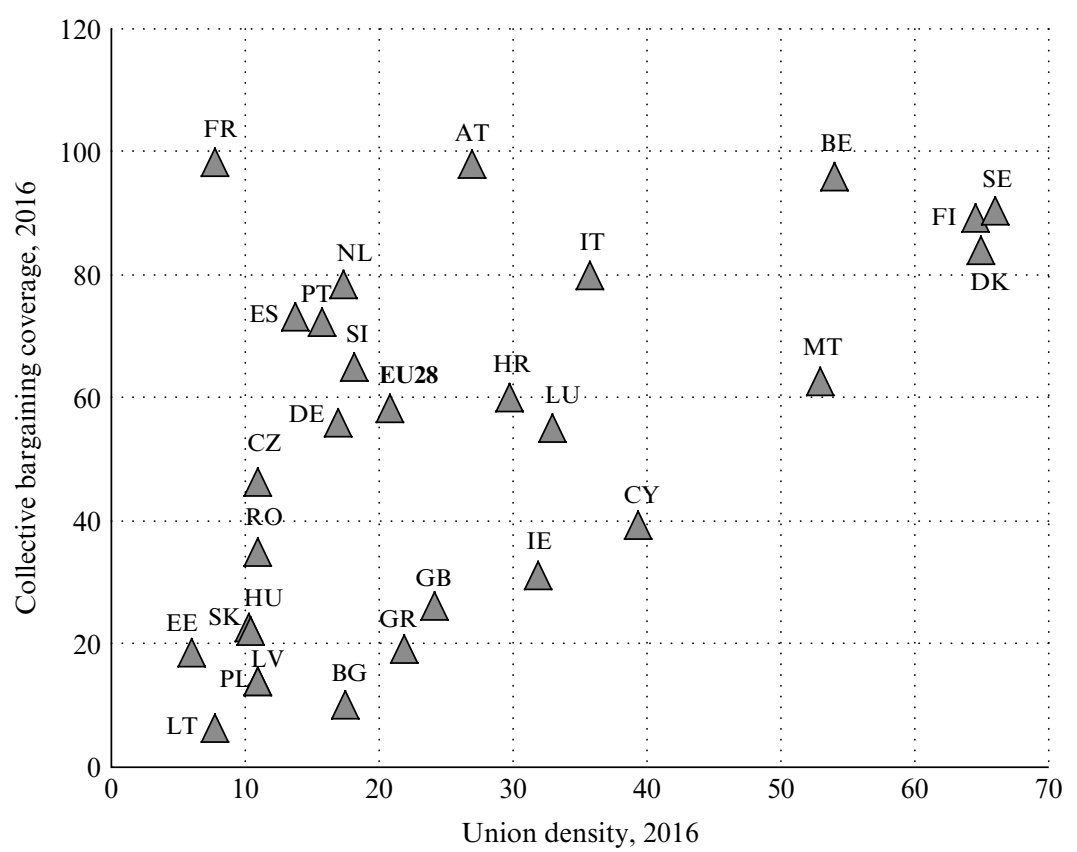

Figure 1.2 Collective bargaining coverage and trade unionisation, by country and EU28, 2016

Latvia and Lithuania with less than 10 per cent on both rates), Poland, Slovakia, Bulgaria and Hungary.

The question is, how did the two variables, collective bargaining and union density, move over the period 2000 to 2016? Can such movements shed light on the relationship between the two variables that we observe in Figure 1.2? Figure 1.3 shows that falling union density is associated with falling collective bargaining coverage, so it is not surprising to see that in 2016 the two variables had a positive correlation. Figure 1.3 also shows that only a few countries (Finland and Malta) experienced an increase in collective bargaining coverage between 2000 and 2016 - because almost all countries were at best at, but generally lower than, the zero level - and all countries (except Belgium, France and Italy) experienced a 10 per cent or more decline in union membership, with extreme cases such as the Czech Republic, Estonia, Latvia, Romania and Slovakia, where the decline was above 55 per cent. Figure 1.3 shows an overall weakening of industrial relations among the EU28, with very few countries (eight out of the 28) showing almost no change over the 17 years in collective bargaining coverage, while all other countries declined. Figure 1.3 seems to show a divide between the above countries and another group of countries - generally older EU member states - that experienced some erosion, but not to the same extent.

Figure 1.4 completes the trio of illustrations to show that countries with higher levels of collective bargaining coverage in 2016 are the countries that experienced a lower decline in union density over the 17 years (2000-2016). 


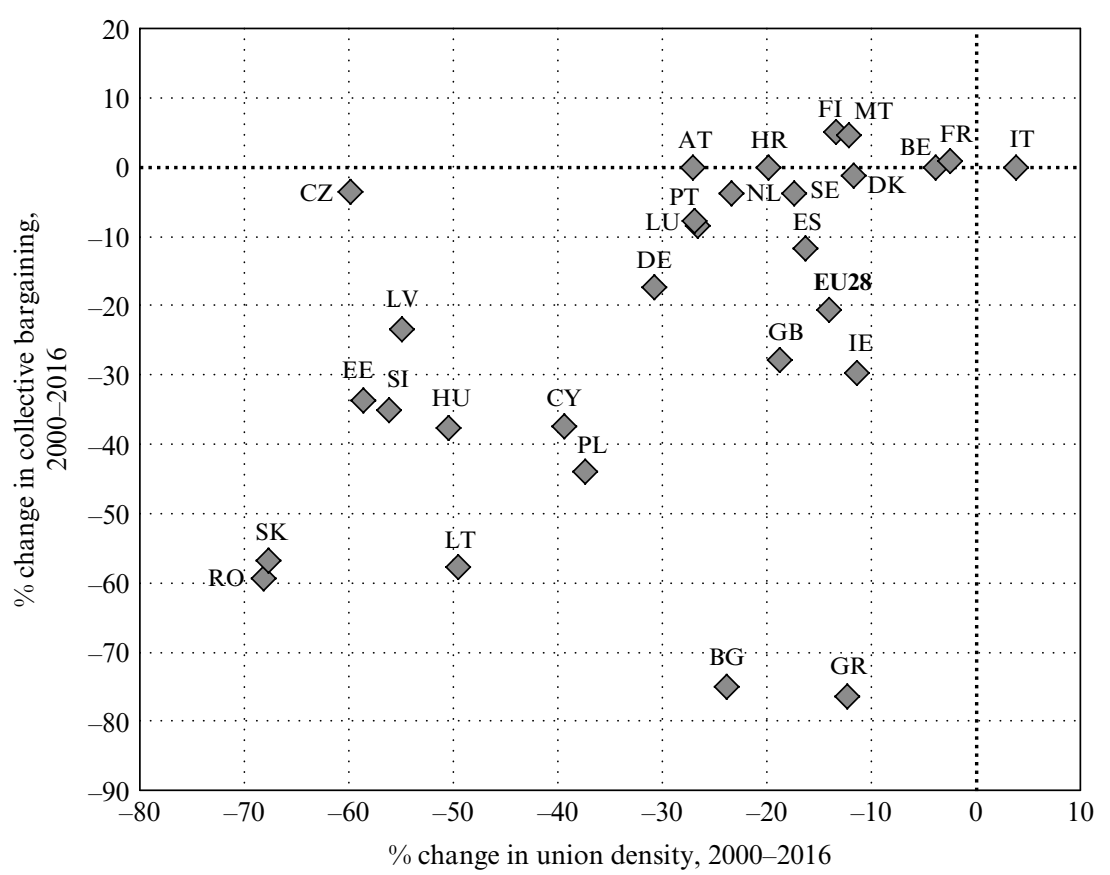

Figure 1.3 Collective bargaining coverage and trade unionisation, by country and EU28, 2000-2016

Figures 1.2 to 1.4 show the weakening of industrial relations among the EU28 leading up to 2016 using two well-known outcomes of labour market institutions in the EU. It is interesting to further explore the evolution of industrial relations over each of the 16 years for which we have data. Since both collective bargaining coverage and union density show similar trends, we select the former to clarify the analysis.

Figure 1.5 shows how the distribution of collective bargaining coverage evolved from 2000 to 2016. The figure confirms a continuous decline over the 17 years, with the exception of the crisis years, which show some resilience in some countries, before a collapse in 2010-11 under the influence of fiscal consolidation programmes in several countries. Between 2000 and 2016 the median value decreased, while the dispersion widened, with an elongated rectangle in 2016 compared with 2000: greater dispersion with lower median would be consistent with the scenario of downward convergence (or scenario 3) on industrial relations among the EU28. How does this compare with the evolution of the LSSI as described in Figure 1.1?

One of the key elements of Figure 1.1 was the dynamics of the weighted median for each of the years for which we estimated a box-plot. The median marks a year-to-year distinction between countries among the EU28 whose LSSI is above or below; that is, countries - and the population in Europe - that on average are below or above the summary measure that indicates the goals of the EPSR.

Figure 1.6 is our final figure and shows the weighted average in terms of collective bargaining coverage among countries (and the respective populations) with an LSSI 


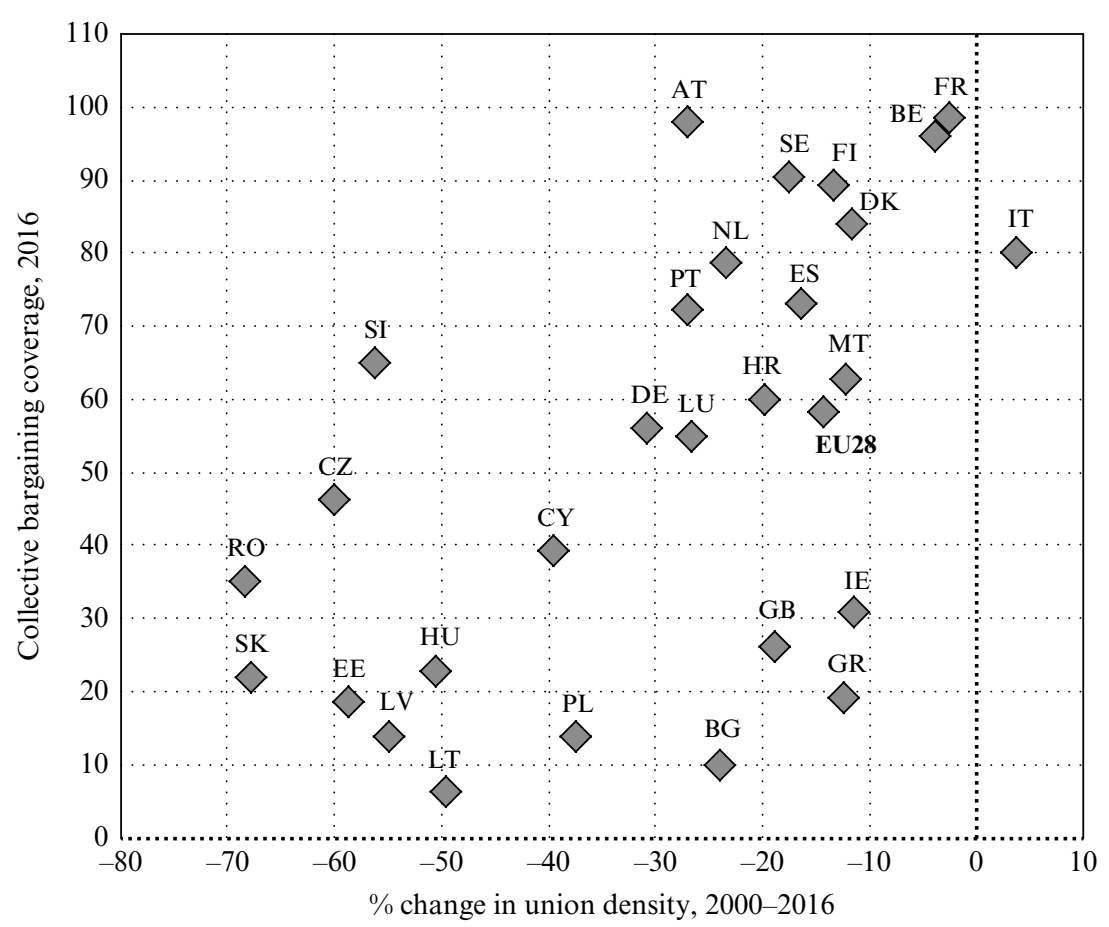

Figure 1.4 Collective bargaining coverage (2016) and changes in trade unionisation density, by country and EU28, 2000-2016

above the median versus countries (and their populations) with LSSI below the median. This figure is quite telling: countries with LSSI below the median (their labour market and social dynamics indicator are below the EU28 weighted median) consistently show a lower proportion of workers covered by collective bargaining compared with countries with labour market and social dynamics indicators which are above the EU28 median. In the period following the global financial crisis, countries which registered more solid labour market and social conditions (LSSI above the median) also showed a return to higher values of collective bargaining coverage despite a 10 per cent drop during the period 2006-07. From then onwards, collective bargaining coverage was maintained almost constantly at about 80 per cent. Among countries with an LSSI below the EU28 weighted median, collective coverage declined gradually from 2009. At the end of the period, collective coverage among the LSSI group below the EU28 median was 17.5 per cent lower compared with 2000. In summary, Figure 1.6 suggests that stronger industrial relations, as summarised and measured by collective bargaining coverage, is not conducive to lower labour market dynamics and socio-economic related outcomes. Instead, the evidence cannot reject that stronger industrial relations can be related to the positive outcomes that the EU aims at promoting through the principles and rights defined by the EPSR.

The national chapters in this volume further document this relationship. They seem to confirm that the countries that have experienced some weakening of their industrial 


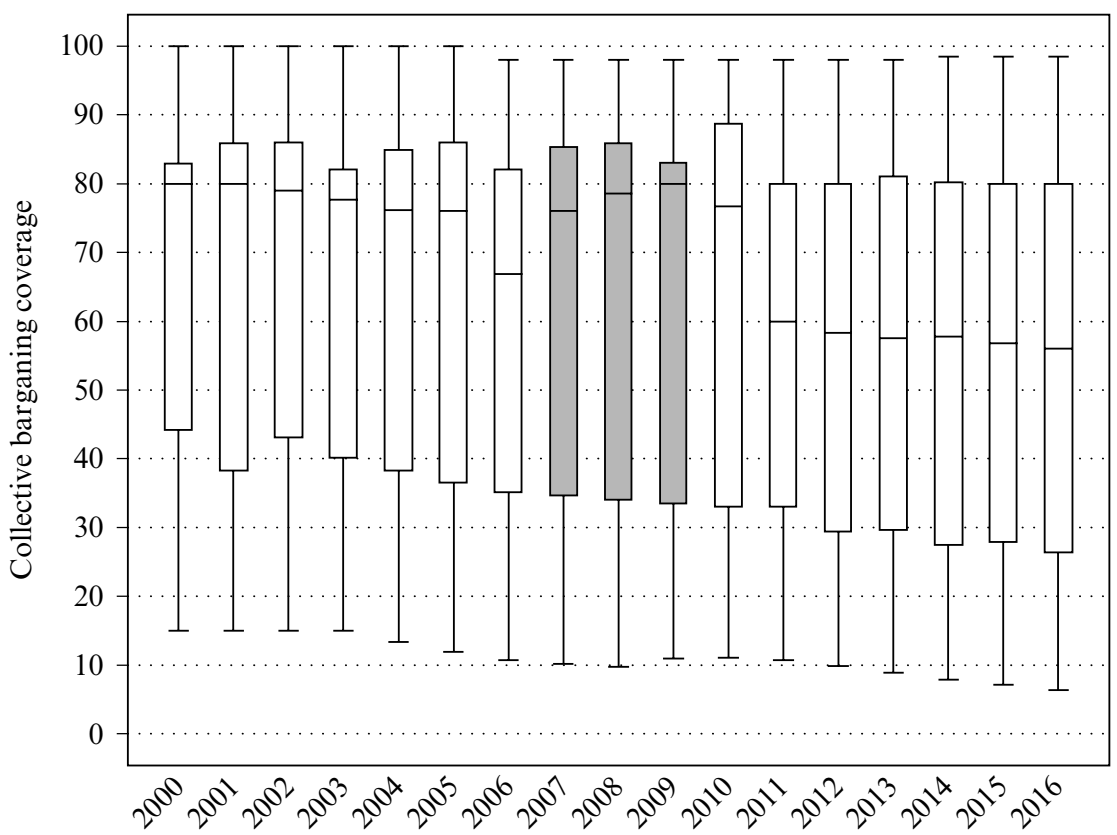

Note: ILO own estimates.

Figure 1.5 Changes in the collective bargaining coverage rate, EU28, 2000-2016 (all individual years)

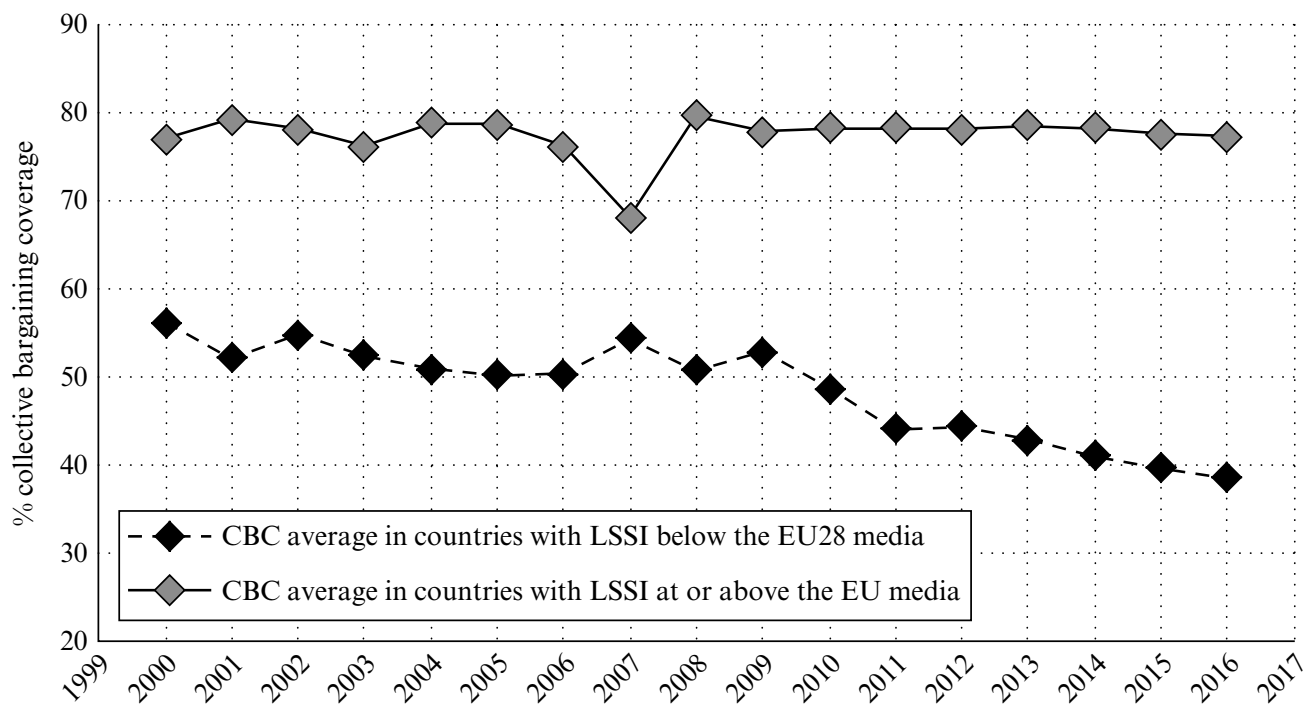

Figure 1.6 Evolution of collective bargaining coverage, EU28 by LSSI distribution, 2000-2016 
relations systems during the crisis (Greece, Portugal and Spain) have also experienced the most substantial decline in their labour market and social indicators. ${ }^{8}$ While countries such as Greece, Spain and Portugal were on the way to convergence towards the EU28 average, they seem to have started diverging from the crisis onwards. This process of divergence seems to be prolonged, as explained in the chapter on Portugal in this volume. Slovenia, a country known for its strong industrial relations system - in particular at tripartite level - has experienced a significant weakening of industrial relations mechanisms over recent years (see the chapter on Slovenia in this volume), and has undergone a deterioration of its LSSI (from tenth to thirteenth place).

The crisis seems thus to have brought about some divergence in industrial relations in the EU. Mechanisms of bargaining coordination, notably on wages, seem to have been interrupted in the countries hit hardest by the recession. Consequently, there seems to be a sort of divide between a group of countries with more cohesive and coordinated industrial relations and wage bargaining institutions, as well as lower inequality levels that are reflected in a better LSSI, and another group of countries in which industrial relations are more uncoordinated, and income equality and LSSI levels are lower. A number of central and eastern European countries have greatly improved their LSSI alongside economic growth, but with little development of their industrial relations systems. While those countries have benefited from 'newcomers' growth, with sudden access to the whole EU market and to some EC funding, they may have more difficulties maintaining their current growth rate in the future. The dramatic reduction of industrial relations in these countries may render their progress with regard to the LSSI more difficult.

\section{CONCLUSIONS}

The analysis proposed in this chapter and the national chapters seems to lead to three important conclusions.

First, an analysis of the convergence of EU countries over the past 16 years shows that, after upward convergence until 2007, the crisis has changed the picture and led to rapidly increased dispersion, so that over this long-term period (2000-2016), EU countries appear to have diverged rather than converged on the fulfilment of socio-economic indicators. We have tried to summarise trends in social and labour market indicators that are fully relevant for the achievement of the EPSR. The results show a greater divergence between countries. This is a worrying trend, even if more encouraging progress is reported in recent years in the national chapters in this volume.

The second conclusion is that such erosion of social indicators has also been extended to industrial relations with a general decline in collective bargaining coverage and trade unionisation. In many countries, the fall in those two indicators is above 50 per cent over 17 years. A certain divide as regards industrial relations can also be observed, between a group of countries with more resilient industrial relations and lower inequality levels, and another group of countries in which industrial relations have been weakened and income inequality increased. A number of newer EU members are also continuing their economic growth with little development of their industrial relations systems. This process may undermine the sustainability of their growth in the future, as shown by the severe adjustments they had to absorb during the crisis. 
Third, this volume shows that the resilience of industrial relations has often coincided with improved performance and better resilience to the crisis. Our analysis in this chapter confirms that stronger industrial relations, as summarised and measured by collective bargaining coverage, is not conducive to lower (a decline in) labour market dynamics and socio-economic related outcomes, but can, on the contrary, be related to positive outcomes with regard to the EPSR. The chapters in this volume seem to confirm this through more detailed evidence. Collective bargaining in particular has helped to negotiate alternatives to layoffs and has assisted many countries in maintaining their level of labour and social indicators. Some collective agreements presented in this volume succeeded in reducing inequalities with regard to access to jobs, social protection and pensions, and to better protect workers confined in part-time employment, temporary contracts, self-employment or in new forms of jobs and working arrangements. Other agreements have permitted employees to achieve a better balance between work and family life. Higher levels of trade unionisation and collective bargaining coverage of women seem to have had a positive effect on narrowing the gender pay gap.

The development of national industrial relations institutions, such as minimum-wage setting or tripartite pacts, was also found to play a role, especially when the strength of the social partners and autonomous collective bargaining had been eroded. The participation of the social partners in vocational training - as in Germany, Sweden and Belgium - or in company-based training (as in France) has also helped in facilitating access to good quality jobs.

Another conclusion from the analysis presented in this chapter is that better measurement of convergence with regard to ESPRs might be needed. We saw the value of the tools and analysis proposed in this chapter as a basis for constructing a solid and comprehensive Summary Indicator that would help in capturing the trends on indicators related to the EPSR. We hope this volume will stimulate further research in that direction.

In summary, the different chapters try to respond to the main question of this volume: are industrial relations helping EU countries in their pursuit of social and economic convergence? If the impact of different elements of industrial relations on socio-economic convergence indicators is somehow confirmed through the reading of this volume - while the EC in its social pillar agenda concludes that such socio-economic indicators definitely contribute to economic growth and convergence - then industrial relations should definitely be treated as a key lever for achieving cross-country convergence.

In this respect we hope that this volume will help to complement policy-makers' views and the options available to them, and that instead of weakening or dismantling industrial relations as obstacles or constraints on the road to convergence, they will opt to maintain and even strengthen such institutions so that they can release their full potential for sustainable growth and a return to convergence.

\section{NOTES}

1. Address given by Jean Monnet at the session to sign the ECSC Treaty at the Quai d'Orsay, Paris, 19 March 1951, p.2, accessed 9 January 2019 at https://www.cvce.eu/obj/address_given_by_jean_monnet_at_the_ses sion_to_inial_the_ecsc_treaty_paris_19_march_1951-en-5752bf8f-4cfa-4553-bcbf-0cc14fcfa37b.html.

2. http://ec.europa.eu/social/BlobServlet?docId=17625\&langId=en (accessed 9 January 2019). A social scoreboard has been established as part of the Pillar to monitor progress on the ground. It will expand and 
replace the existing scoreboard of key economic and social indicators used in the European Semester of economic policy coordination to better take into account social considerations. This will serve to track trends and performances across countries and to inform policy guidance in the context of the European Semester. See https://composite-indicators.jrc.ec.europa.eu/social-scoreboard/ and a brochure http://ec. europa.eu/social/BlobServlet?docId=17613\&langId=en, both accessed on 9 January 2019.

3. Statement by President Juncker at the European Parliament plenary session, Strasbourg, 22 October 2014 , accessed 9 January 2019 at http://europa.eu/rapid/press-release_SPEECH-14-705_en.htm.

4. For recent evidence on the overall impact of social dialogue and industrial relations on inequality, see Vaughan-Whitehead (2018).

5. The other areas are Economic Union, Financial Union, Fiscal Union and Political Union. The EPSR refers to 20 principles and rights that include the right to fair wages and the right to health care, lifelong learning, better work-life balance and gender equality, among others. With a call to member states to commit to a common goal in matters related to such principles, the EU stands for cohesion of these rights among all its citizens in a fast-changing world (www.europa.eu/commission).

6. For some overviews of relevant studies on convergence read Atkinson (2015), EPSC (2015), ILO (2016a) and Alcidi et al. (2018).

7. An estimation of the same dynamics of the LSSI but using unweighted values shows similar results, with the median following the same pattern over time, although at slightly different levels. In general, the unweighted median is slightly below the weighted median, particularly in the post-crisis period. This shows that among countries with larger populations - in particular France and Germany - the LSSI scores higher. The convergence and divergence patterns, however, remain similar between weighted and unweighted estimates.

8. For Greece for instance see ILO (2016b), more generally for social dialogue in the recession see Visser (2016) and for a more general overview on the link between social dialogue and economic performance see Grimshaw et al. (2017).

\section{REFERENCES}

Alcidi, C., J.N. Ferrer, M. Di Salvo, R. Musmeci and M. Pilati (2018), Income Convergence in the EU: A Tale of Two Speeds, Brussels: CEPS.

Atkinson, A.B. (2015), Inequality. What Can Be Done?, Oxford: Oxford University Press.

De Spiegelaere, S. and R. Jagodzinski (2015), European Works Councils and SE Works Councils in 2015: Facts and Figures, Brussels: ETUI.

Eurofound (2017), 'Converging economies, diverging societies? Upward convergence in the EU', Eurofound, Dublin, accessed at https://www.eurofound.europa.eu/fr/events/foundationforum-2017; https://www.eurofound.europa.eu/fr/publications/other/2017/converging-econom ies-diverging-societies-upward-convergence-in-the-eu-foundation-forum-2017.

European Commission (EC) (2015), 'Completing Europe's Economic and Monetary Union', (Five Presidents' report), 22 June, report by J.-C. Junker, Brussels, accessed 9 January 2019 at https:// ec.europa.eu/commission/sites/beta-political/files/5-presidents-report_en.pdf.

European Commission (EC) (2017a), 'Commission Recommendation on the European Pillar of Social Rights', C(2017)2600 final of 26 April 2017, Brussels.

European Commission (EC) (2017b), 'Establishing a European Pillar of Social Rights', COM(2017)250 final of 26 April 2017, Brussels.

European Commission (EC) (2017c), 'Reflection paper on the deepening of the Economic and Monetary Union', COM(2017)291 of 26 April 2017, Brussels.

European Commission (EC) (2017d), 'Monitoring the implementation of the European Pillar of Social Rights', Communication from the Commission to the European Parliament, the Council and the European Economic and Social Committee, SWD(2018) 67 final, 13 March 2018 (COM 2018) 130 Final, Strasbourg.

European Commission (EC) (2018), 'Annual report on intra-EU labour mobility 2017', 2nd edn, September, EC, Brussels.

European Political Strategy Centre (EPSC) (2015), 'The social dimension of economic and monetary union - towards convergence and resilience', EPSC Strategic Notes, Issue 5, 18 May, European Political Strategy Centre EC, Brussels. 
Grimshaw, D., A. Koukiadaki and I. Tavora (2017), Social Dialogue and Economic Performance What Matters for Business - A Review, Geneva: ILO.

International Labour Office (ILO) (2016a), Building a Social Pillar for European Convergence, Geneva: ILO.

International Labour Office (ILO) (2016b), Evaluating the Effects of the Structural Labour Market Reforms on Collective Bargaining in Greece, Geneva: ILO.

Papadakis, K. (ed.) (2011), Shaping Global Industrial Relations: The Impact of International Framework Agreements, Basingstoke: Palgrave Macmillan and Geneva: ILO.

Sapir, A. and G.B. Wolff (2015), 'Euro-area governance: what to reform and how to do it?', Bruegel Policy Brief, February.

Vandenbroucke, F. (2017), 'Structural convergence versus systems competition: Limits to the diversity of labour market policies in the EMU', Discussion Paper 065, July, European Commission, Brussels.

Vaughan-Whitehead, D. (ed.) (2016), Europe's Disappearing Middle Class?: Evidence from the World of Work, Cheltenham, UK and Northampton, MA, USA: Edward Elgar and Geneva: ILO.

Vaughan-Whitehead, D. (ed.) (2018), Reducing Inequalities in Europe: How Industrial Relations and Labour Policies Can Close the Gap, Cheltenham, UK and Northampton, MA, USA: Edward Elgar and Geneva: ILO.

Visser, J. (2016), 'What happened to collective bargaining during the great recession?', IZA Journal of Labor Policy, 5 (1), 1-35. 


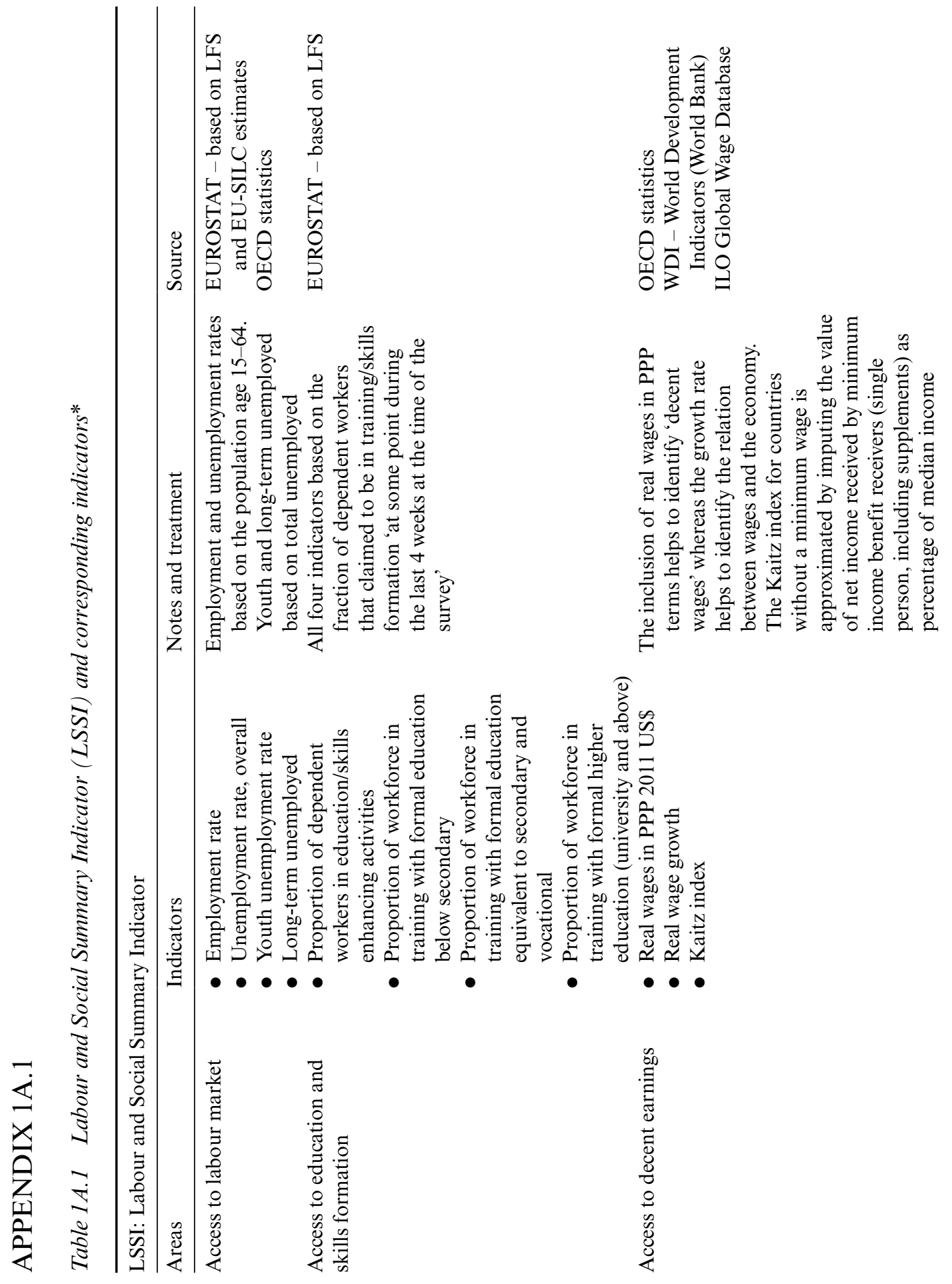




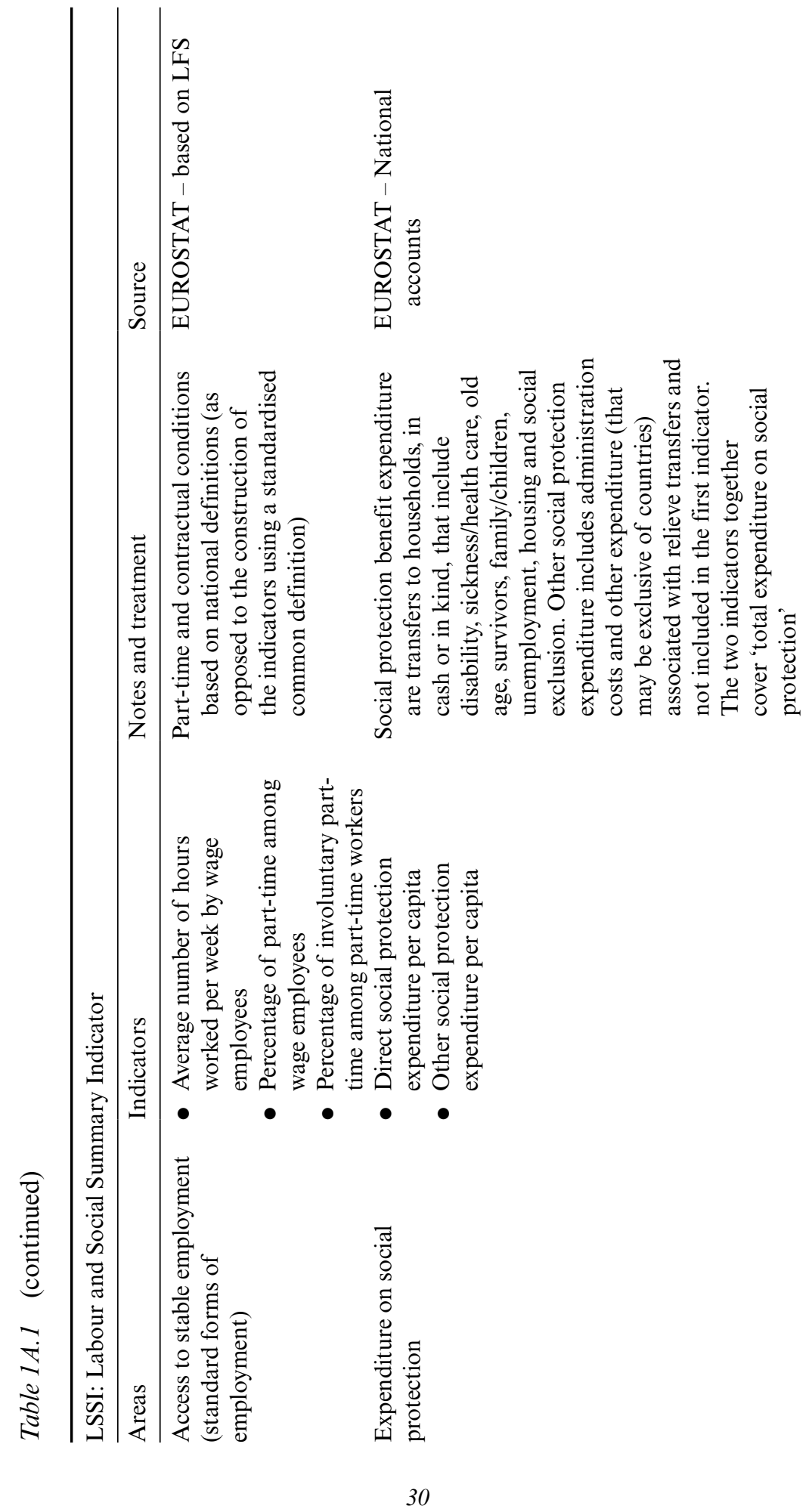



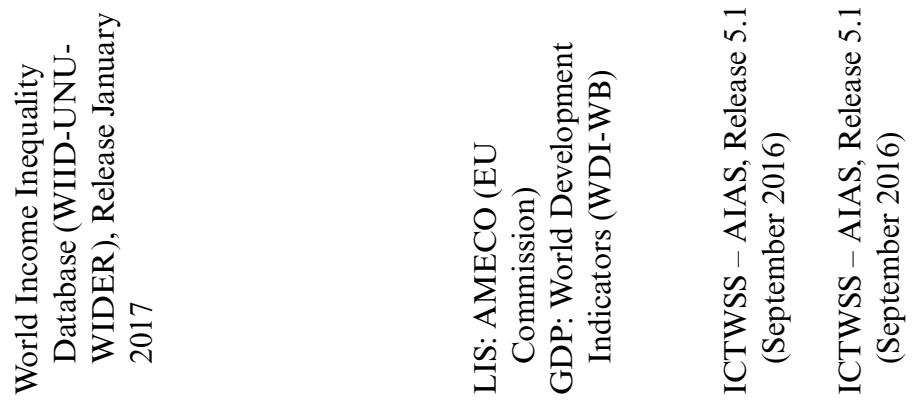

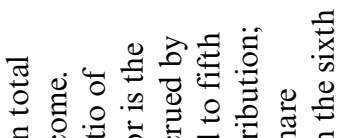

o

可

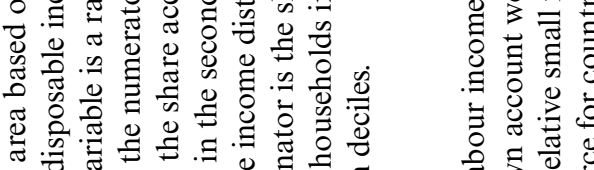

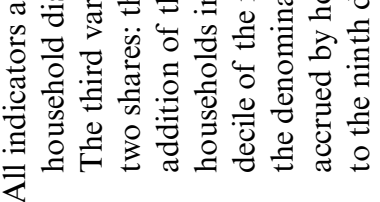

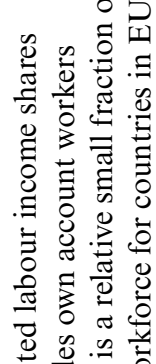

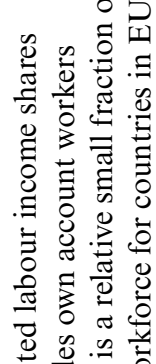

$\leftarrow \stackrel{\infty}{\stackrel{0}{0}}$

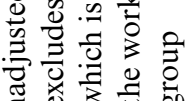

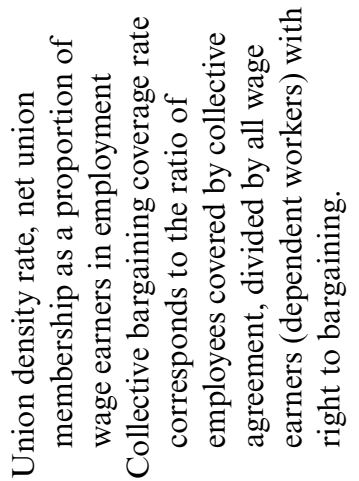

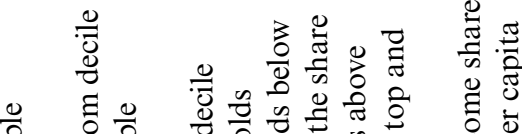

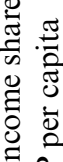

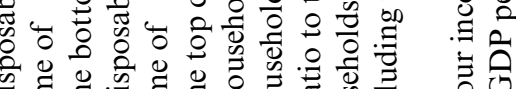

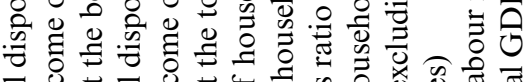

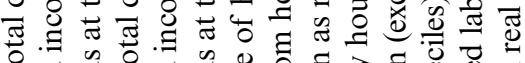

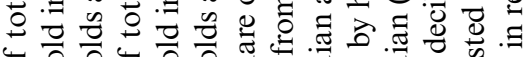

4

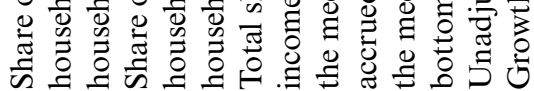

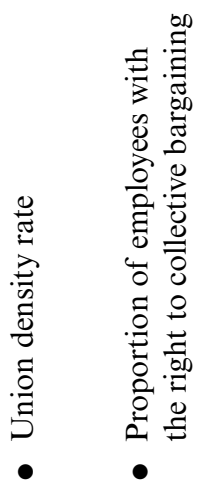

*

艼
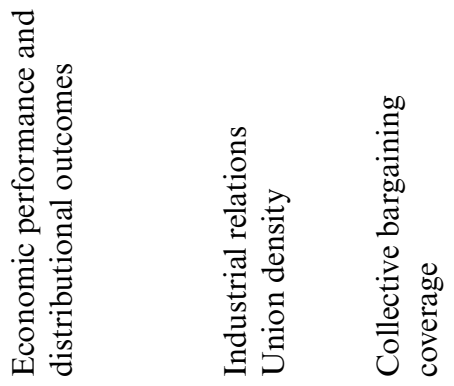


\section{APPENDIX 1A.2 SUMMARISING LABOUR MARKET AND SOCIO-ECONOMIC INDICATORS INTO A CONVERGENCE MEASURE: THE LABOUR AND SOCIAL SUMMARY INDICATOR (LSSI)}

Comparing countries using several indicators can be a complex task. For example, a comparative labour market analysis of the EU28 using employment rates, unemployment rates and involuntary part time would involve reviewing and assessing at least 84 tendencies. The complexity increases when more than three indicators are involved, especially if these are not independent. A solution to this complexity is to construct a measure where the indicators are summarised into a single variable: this technique is what lies behind the construction of well-known indexes such as the Human Development Index (HDI, United Nations Development Programme) or the Better Life Index (BLI, Organisation for Economic Co-operation and Development). In practice, the technique involves constructing a number (a score) for each of the countries involved (or units, or regions) so that these can be compared to each other in equal terms.

Constructing a summary measure relies on two steps. The first step consists of converting each of the indicators into the same unit of measurement, that is, normalising each indictor into a range of values (say, from 0 to 1) where going from one extreme value to the other (say, going from scoring 0 to scoring 1) implies going from lower (less desired outcomes) to higher or more desired outcomes. For example, if we have ten countries with employment rates ranging from 35 per cent to 70 per cent, the country with 35 per cent could be attached a value of 0 and the country with 70 per cent would be attached a value of 1 . All the other eight countries would be attached values higher than 0 but less than 1 where such values (scores) would reflect the within group relative distance in employment rates. The trick behind the normalisation of an indicator is to apply an adequate strategy that assigns each of the intra-range units a value (between 0 and 1) that captures the relative distance between countries. The strategy to construct the LSSI considers the need to normalise indicators so that the scores retain the time series characteristics of the original indicators. This allows us to compare the relative performance of countries at a particular point in time, and the between country and within country performance over time, which is a requirement for measuring convergence. To describe the method let us assume we have data for a sequence of years (for example, 2000-2016 so that the first period is the year 2000), we have ten countries and let us take employment rate as an illustration. In the year 2000, the highest and lowest employment rate among the ten countries is 35 per cent and 70 per cent, so these two values become the lowest and highest base year normalising values, namely, $\underline{m}_{2000}=35$ and $\bar{m}_{2000}=70$. Applying expression (1A.1) to the employment rate of each country at time $\mathrm{t}$, that is, $v_{c t}$, implies attaching a score $n v_{c t}$ to each country in the set:

$$
n v_{c, t}=\frac{v_{c, t}-\bar{m}_{t 0}}{\bar{m}_{t 0}-\bar{m}_{t 0}}
$$

For example, if country $\mathrm{Z}$ among the set of ten has an employment rate of 49 per cent in the year 2000, $v_{z, 2000}=49 \%$ and its normalised score in 2000 will be $n v_{z, 2000}=0.4$. For 
subsequent years, that is, from 2001 to 2016, we keep the same normalising values - in general, $\left(\underline{m}_{0}, \bar{m}_{t 0}\right)$ - to normalise the employment rate of the same group of countries. In the construction of indexes such as the HDI or the BLI, the normalising parameters change at each point in time - that is, they become $\left(\underline{m}_{t}, \bar{m}_{t}\right)$ - so that the scores are only valid to 'rank' countries at a particular point in time. With the normalising strategy in (1A.1), the score values attached to each country retain their cross-section nature (that is, this can still be used as a rank or a comparison measure between countries) but anchoring the normalisation to a base year means that the scores attached to the indicators that are normalised over subsequent years gain a time series dimension: comparing the time movements of the score for a single country shows growth, while comparing the scores between a group of countries shows relative performance between countries that grow or shrink with respect to that particular indicator(s). It can be shown that the properties of the normalised variable using the standard method - that is, $\left(\underline{m}_{t}, \bar{m}_{t}\right)$ - are retained when compared to the modified method in (1A.1). The only condition is that the value of the original indicators cannot grow unbounded while the denominator in (1A.1) has to be positive. It is rare to find a situation where these two conditions are not met. Finally, one of the conditions to normalise indicators is that once these are normalised all of them follow the same directional interpretation (low values implies less desired outcomes, higher values more desired outcomes). In the case of employment rates a 'higher is better' would be a reasonable desire, but in the case of unemployment, for example, the opposite is true. When the nature of indicators is such that 'lower is a more desired outcome', then the normalisation of the indicator consists of subtracting from 1 the result obtained

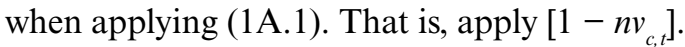

The second and final step consists of joining all the normalised indicators into a single measure. This can be achieved by taking a simple average between the score values of all the normalised indicators, for each country and at each point in time. For example, if we have 28 countries and 20 indicates, add the score values of the 20 normalised indicators for each country, and divide these by 20 . The result is an indicator of dimension $1 \times 28$.

With the above reading of the index, it becomes clear that the treatment of the so-called 'controversial indicators' is such that countries with the highest value (for example, with the highest permanent employment rate) will receive a higher score from this particular indicator. However, the construction of the LSSI does not imply that countries have to pursue a maximal or minimal strategy on any particular indicator for EU28 convergence on the EPSR. Instead, the analysis is such that, at any given point in time, countries are scattered over a range of values as a result of their underlying indicators. Identifying convergence involves examining the changes in the distribution of the LSSI values over a sufficient time span (in the case of this chapter this amounts to the period 2000-2016) comparing such movements to the first year of the analysis (in this case, 2000). The slight modification in the construction of the LSSI relative to the construction of measures such as the HDI or the BLI, to mention just two, provides the LSSI with a time-series dimension that validates the use of the measure as one of convergence or divergence from some initial point in time.

The distributional changes of the LSSI can also shed light on the relationship between industrial relations, and its evolution, and the evolution of labour market and social dynamics. This completes the circle in Chapter 1 because the evolution of industrial 
relations is at the heart of each chapter in this volume. Again, trying to compare 20 independent indicators with those frequently used to capture industrial relations (for example, collective bargaining coverage and union density) could bring too much complexity into the analysis, while using the LSSI reduces the problem to a single dimension. 